ISSN (print): 1698-6180. ISSN (online): 1886-7995

www.ucm.es/info/estratig/journal.htm

Journal of Iberian Geology 38 (2) 2012: 331-348

http://dx.doi.org/10.5209/rev_JIGE.2012.v38.n2.40462

\title{
First report of a Middle-Upper Permian magmatism in the SE Iberian Ranges: characterisation and comparison with coeval magmatisms in the western Tethys
}

\section{Primeros datos del magmatismo pérmico medio-superior del SE de la Cordillera Ibérica: caracterización y comparación con magmatismos contemporáneos del Tethys occidental}

\author{
M. Lago ${ }^{1 *}$, R. de la Horra ${ }^{2,4}$, T. Ubide ${ }^{1}$, C. Galé ${ }^{1}$, B. Galán-Abellán ${ }^{2,4}$, J.F. Barrenechea ${ }^{3,4}$, J. López- \\ Gómez $^{2,4}$, M.I. Benito ${ }^{2,4}$, A. Arche ${ }^{2,4}$, J. Alonso-Azcárate ${ }^{5}$, F.J. Luque ${ }^{3,4}$, M.J. Timmerman ${ }^{6}$ \\ ${ }^{1}$ Departamento de Ciencias de la Tierra. Univ. Zaragoza, C/ Pedro Cerbuna s/n, 50009 Zaragoza, Spain \\ mlago@unizar.es; tubide@unizar.es; carlosga@unizar.es \\ ${ }^{2}$ Departamento de Estratigrafia, Fac. de Ciencias Geológicas, Univ. Complutense de Madrid, 28040 Madrid, Spain \\ abgalan@geo.ucm.es; rhorraba@geo.ucm.es; jlopez@geo.ucm.es; mibenito@geo.ucm.es; aarche@geo.ucm.es \\ ${ }^{3}$ Departamento de Cristalografía y Mineralogía, Fac. de Ciencias Geológicas, Univ. Complutense de Madrid, 28040 \\ Madrid,Spain.carrene@geo.ucm.es; jluque@geo.ucm.es \\ ${ }^{4}$ Instituto de Geociencias (CSIC, UCM), C/ José Antonio Novais 2, 28040 Madrid, Spain \\ ${ }^{5}$ Fac. Ciencias del Medio Ambiente, Univ. Castilla-La Mancha, Toledo, Spain. jacinto.alonso@uclm.es \\ ${ }^{6}$ Institut für Erd- und Umweltwissenschaften, Univ. Potsdam, Karl-Liebknecht-Str. 24-25, 14476 Potsdam-Golm, Germany. \\ timmer@geo.uni-potsdam.de \\ *corresponding author
}

Received: 12/10/2011 / Accepted: 25/05/2012

\begin{abstract}
A multiple basic to intermediate sill is reported for the first time in the south-eastern Iberian Ranges. It is composed of several tabular to irregular levels intercalated within the fluvial sediments of the Alcotas Formation (Middle-Upper Permian). The sill could represent the youngest Paleozoic subvolcanic intrusion in the Iberian Ranges.

The igneous rocks are classified as basaltic andesites. They show a subophitic microstructure constituted by plagioclase (An62 - An6), augite (En48Wo44Fs7 -En46Wo39Fs15), pseudomorphosed olivine, minor amounts of oxides (magnetite and ilmenite) and accessory F-apatite. According to the mineralogy and whole-rock composition, their geochemical affinity is transitional from subalkaline to alkaline.

Radiometric dating of the sill is not feasible due to its significant alteration. Field criteria, however, suggest an emplacement coeval to the deposition of the Alcotas Formation (Middle-Upper Permian). This hypothesis is supported by the transitional affinity of these rocks, similar to other Middle-Upper Permian magmatisms in the western Tethys, e.g., from the Pyrenees.

Taking into account their isotopic signature $\left(\varepsilon_{\mathrm{Sr}}:-6.8\right.$ to $-9.2 ; \varepsilon_{\mathrm{Nd}}:+1.7$ to +8.3$)$, an enriched mantle source with the involvement of a HIMU component has been identified. This interpretation is supported by the trace element contents.
\end{abstract}


Some of these HIMU characteristics have been recognised in the Middle-Upper Permian magmatisms of the Central Pyrenees (Anayet Basin) and the High Atlas (Argana Basin). However, none of these source features are shared with other Middle-Upper Permian magmatisms of the western Tethys (Catalonian Coastal Ranges, Corsica-Sardinia and southern France), nor with the Lower Permian magmatism of the Iberian Ranges. These differences support the presence of a heterogeneous mantle in the western Tethys during the Permian.

Keywords: sill, peperite, subalkaline to alkaline magmatism, Middle-Upper Permian, Iberian Basin

\section{Resumen}

Se describe por primera vez en el sudeste de la Cordillera Ibérica un sill múltiple de carácter básico a intermedio. Está compuesto por varios cuerpos tabulares a irregulares intercalados entre los sedimentos de origen fluvial de la Formación Alcotas (Pérmico Medio-Superior). El sill podría representar la intrusión subvolcánica paleozoica más reciente en la Cordillera Ibérica.

Estas rocas subvolcánicas se clasifican como andesitas basálticas. Muestran una textura subofítica constituida por plagioclasa (An62 - An6), augita (En48Wo44Fs7 -En46Wo39Fs15), pseudomorfos de olivino, minerales opacos (magnetita e ilmenita) y F-apatito accesorio. De acuerdo con su composición mineral y de roca total, su afinidad geoquímica es transicional entre subalcalina y alcalina.

La datación radiométrica del sill no es posible debido a su elevado grado de alteración. No obstante, los criterios de campo sugieren un emplazamiento contemporáneo con el depósito de la Formación Alcotas (Pérmico Medio-Superior). Esta hipótesis está apoyada por la afinidad transicional de estas rocas, similar a otros episodios magmáticos del Pérmico Medio-Superior en el Tethys occidental, como los que afloran en los Pirineos.

Teniendo en cuenta su signatura isotópica $(\varepsilon \mathrm{Sr}:-6.8 \mathrm{a}-9.2 ; \varepsilon \mathrm{Nd}:+1.7 \mathrm{a}+8.3)$, se propone un origen a partir de un manto enriquecido, con la participación de un componente de tipo HIMU. Esta interpretación está apoyada por sus contenidos en elementos traza.

Algunas de estas características del protolito han sido reconocidas en los magmatismos del Pérmico Medio-Superior del Pirineo (cuenca del Anayet) y del Alto Atlas (cuenca de Argana), pero no son habituales en otros magmatismos de edad Pérmico Medio-Superior del Tethys occidental (Cadenas Costero Catalanas, Córcega-Cerdeña y Sur de Francia), ni en el magmatismo Pérmico Inferior de la Cordillera Ibérica. Estas diferencias apoyan la presencia de un manto heterogéneo en el Tethys occidental durante el Pérmico.

Palabras clave: sill, peperita, magmatismo subalcalino a alcalino, Pérmico medio-superior, Cuenca Ibérica

\section{Introduction}

The Iberian Basin was developed as an intracratonic basin during the Middle-Upper Permian and underwent several extensional periods during the Mesozoic and Cenozoic, when two major compressive events caused structural inversion leading to the present-day configuration of the Iberian Ranges (Arche and López-Gómez, 1996; Van Wees et al., 1998; Vargas et al., 2009). This configuration shows two almost parallel NW-SE oriented domains: the Aragonian Branch to the north and the Castilian Branch to the south; they are separated by the Cenozoic Calatayud-Teruel Basin (Fig. 1). The Iberian Basin was related to other contemporaneous basins such as the Pyrenean and Catalonian Basins (Arche and López-Gómez, 1996), which experienced similar phases of evolution during their first stages along the Permian and Triassic (e.g., Vargas et al., 2009).

The first main macrosequence filling the Iberian Basin during the Permian is an unconformity-bounded succession consisting of two units: the Boniches Formation and the Alcotas Formation (Fig. 2). This work is focused on the Alcotas Formation, which corresponds to the first period of widespread continental sedimentation in the Iberian Basin and was deposited in a series of inter- or semi-connected, asymmetric half grabens trending NW-
SE. This situation represents an embryonic stage of development of the Iberian Basin (Fig. 3).

During the Middle-Upper Permian, coeval sediments were deposited in isolated pull-apart basins within the western Tethys. For instance, in the Iberian micro-plate the Cantabrian-Pyrenean domain (López-Gómez et al., 2002, 2005) was related to the Bay of Biscay megashear, and the Catalonian-Levantine domain (Arche et al., 2002, 2004) was related to the antithetic shear fault system in the north-eastern edge of the Iberian microplate (Christie-Blick and Biddle, 1985). These basins constituted a mosaic of connected or semi-connected rift systems (Fig. 3) that enabled the ascent of mantlederived magmas. Associated subvolcanic bodies of transitional affinity have been recognised intruding the mentioned coeval sediments in several localities of the Cantabrian-Pyrenean domain (e.g., Lago et al., 2004a) and southern France (Lapierre et al., 1999) or intruding plutonic rocks in the Pyrenees (Gil et al., 2011), the Catalonian Coastal Ranges (Ubide et al., 2010) and Corsica-Sardinia (Traversa et al., 2003).

In this paper we present the first evidence of magmatic bodies emplaced within the fluvial sediments of the Alcotas Formation. The aim of this work is to characterise the petrology and geochemistry of these intrusions and to define their emplacement age. 


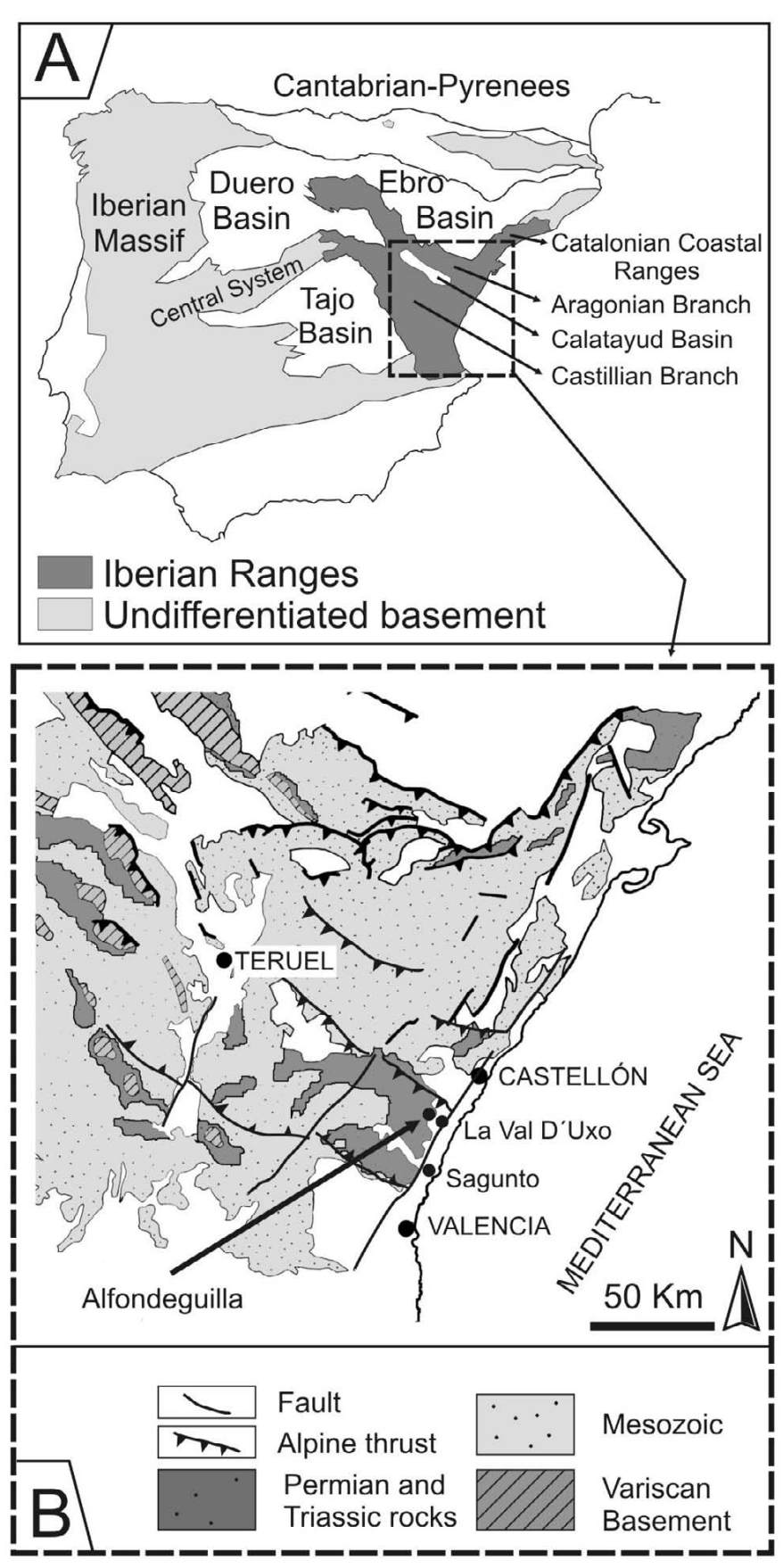

Fig. 1.- A- Main geologic units of the Iberian Peninsula. B- Presentday configuration of the Iberian Ranges and locations cited in the text.

Fig. 1.- A- Principales unidades geológicas de la Península Ibérica. B- Configuración actual de la Cordillera Ibérica y posición de las localidades citadas en el texto.

\section{Geological context}

The Alcotas Formation crops out for more than $250 \mathrm{~km}$, from Molina de Aragón to the present day Mediterranean coast, in the central and south-eastern domains of the Iberian Ranges, but it is not present in the north-western domain or in the Central System. Based on palynologi- cal data, its age has been considered Thüringian (Doubinger et al., 1990) or, more recently, late Guadalupian to early Lopingian (Bourquin et al., 2011; De la Horra et al., 2012). Hereafter, we will consider it as Middle-Upper Permian.

The Alcotas Formation reaches $170 \mathrm{~m}$ in thickness and consists of red siltstone and claystone beds alternating with lenticular sandstones and sporadic conglomerate lenses. Beds are tens to hundreds metres long and decimetric to metric in thickness (Arche and López-Gómez, 2005; De la Horra et al., 2008); according to these authors, the Alcotas Formation can be divided into three subunits from base to top: the Lower Part, the Middle Part and the Upper Part. The mineral assemblage consists of quartz + feldspar + illite + hematite \pm dolomite (Alonso-Azcárate et al., 1997). The Alcotas Formation lies conformably on the Boniches Formation or unconformably on the Variscan basement. It is unconformably overlain by the Early Triassic Valdemeca Unit or by the Cañizar Formation (Fig. 2).

The Lower Part shows abundant channelized sandstone bodies with planar cross-stratification and high avulsion rate embedded in a wide fine-grained floodplain (Arche and López-Gómez 2005). It is interpreted as gravely and sandy braided river deposits in an arid to semi-arid climate with marked seasonality (Benito et al., 2005; De la Horra et al., 2008).

The Middle Part consists of mudstones and siltstones with interbedded thin bodies of sandstone with epsilon cross-stratification littered by comminuted plant remains. Preserved plant remains and tree trunks indicate periods of humid conditions (Diéguez et al., 2007). It is interpreted as a transition from distal sandy braided rivers to high sinuosity meandering rivers occurring gradually yet rapidly (Arche and López-Gómez, 2005).

The Upper Part consists of siltstones with intercalated thin sandstone bodies, where neither paleosols nor macro- or micro-flora has been found. Sandstone bodies contain planar cross-stratification and current ripples. It is interpreted as very low-energy sandy braided river system with high avulsion rate related to the lack of vegetated cover (Arche and López-Gómez, 2005).

Six magmatic levels have been identified intruding the Alcotas Formation in the eastern outcrops of the unit, close to the Alfondeguilla village (Castellón province, Fig. 1). The Alfondeguilla section shows an incomplete sedimentary succession due to different fault displacements related to Alpine tectonics. In spite of this, a succession of $64 \mathrm{~m}$ is well exposed (Fig. 4; UTM: 30S 0734751 4415013). This section corresponds mostly to the Middle and Upper Parts of the Alcotas Formation. The magmatic levels intrude the Middle and Upper Parts of this unit. 


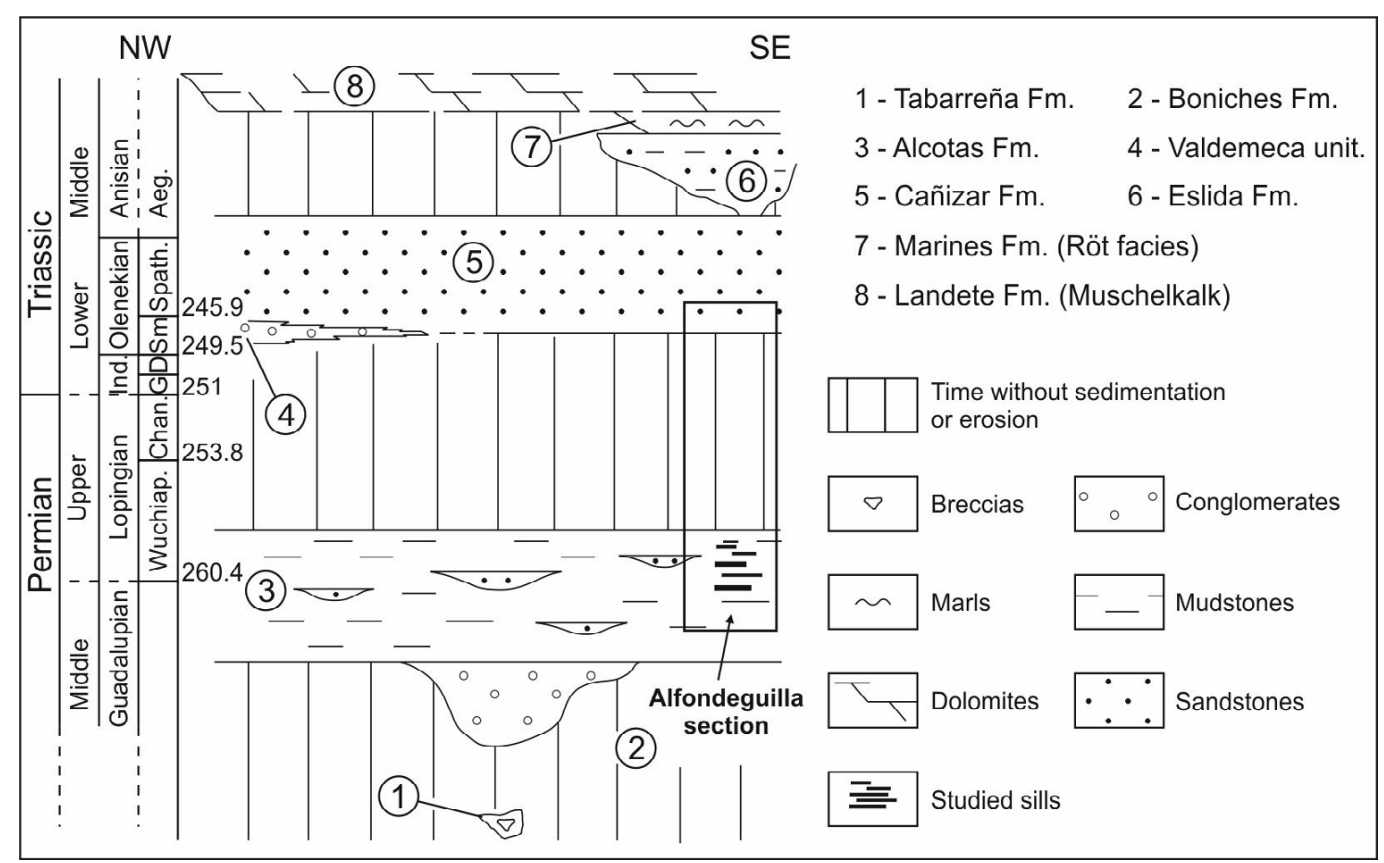

Fig. 2.- Scheme of the Permian and Triassic sedimentary successions in the SE Iberian Ranges and associated unconformities and hiatuses. The studied igneus rocks are intercalated into the Alcotas Formation.

Fig. 2.- Esquema de las sucesiones de rocas del Pérmico y Triásico en el SE de la Cordillera Ibérica y las discordancias e hiatos asociadas. Las rocas ígneas estudiadas aparecen intercalados en la Formación Alcotas.

The studied area was located at the junction of two major fracture zones during the Permian: the Iberian (NWSE trending) and the Catalonian-Levantine (NNE-SSW) (Arche and López-Gómez, 1999; Fig. 3). The latter zone, located along the eastern margin of the Iberian microplate, was developed in a different extensional domain that extended from Provence down to the Levantine area, starting the process of separation of the future small insular blocks to the east (Arche et al., 2002).

\section{Field observations}

Six igneous levels have been recognised in the Alfondeguilla section; we have named them ALFx1 to ALFx6 from top to bottom in the stratigraphical sequence (Fig. 4). The levels are grey coloured, with a brownish hue at the most altered areas. They present an average NE-SW strike and are subhorizontal (042,06NW - 056, 20SE), occurring along sedimentary bedding planes. They show a tabular to irregular shape (Fig. 5A) and crop out for up to $160 \mathrm{~m}$. Their thickness varies from $20 \mathrm{~cm}$ to more than $3 \mathrm{~m}$ and it generally decreases towards the upper levels (Fig. 4). The levels are vertically separated by 1.5 to 3.6 $\mathrm{m}$ of sedimentary rocks and are closer to each other towards the upper levels. Both the igneous levels and the sedimentary country-rocks are affected by a network of fractures with two main directions: NNE-SSW $(020,90)$ and ESE-WNW $(115,80 \mathrm{SE})$. Some fractures are filled with calcite.

In detail, the contact of the igneous levels and the sedimentary country-rocks is generally sharp but wavy (Fig. 5A). Irregular contacts are characterised by smooth, ovoid or elongate, cm-scale undulations that curve outwards from intrusive margins and are separated by cuspate, sediment-filled invaginations. According to Befus et al. (2009), these structures can be considered as billows (Fig. 5A). Besides, irregular, cm-scale fragments of structure-less sediments are frequently observed inside the intrusions (Fig. 5B-D), close to their margins. Locally, in the ALFx4 and especially ALFx6 levels (Fig. 4), which are the thickest, we have recognised igneous rocks intermixed with the country-rock sediments: rounded, $\mathrm{cm}$-scale globules of igneous rock surrounded by sediments, partly replace the upper margin of this intrusion (Fig. 5E). These structures are considered peperites as defined by White et al. (2000) and Skilling et al. (2002).

The igneous levels develop chilled margins with frequent, rounded, calcite-filled vesicles (Fig. 5C-E). The vesicles are sometimes elongated and even coalesced, oriented parallel to the sill margin. They are millimetric to centimetric in size and their proportion is greater at the thicker, stratigraphically lower levels (ALFx4 to ALFx6), becoming scarcer towards the upper levels. The igneous rocks are rather homogenous, both throughout the vertical of the levels and along their length. They usually present non oriented mm-sized phenocrysts, visible to the naked eye; most of them are red-coloured, altered olivine crystals.

\section{Samples and methods}

Excepting ALFx1, which shows the highest alteration degree, the rest of the igneous levels (Fig. 4) were sampled for petrological and geochemical studies. The sam- 


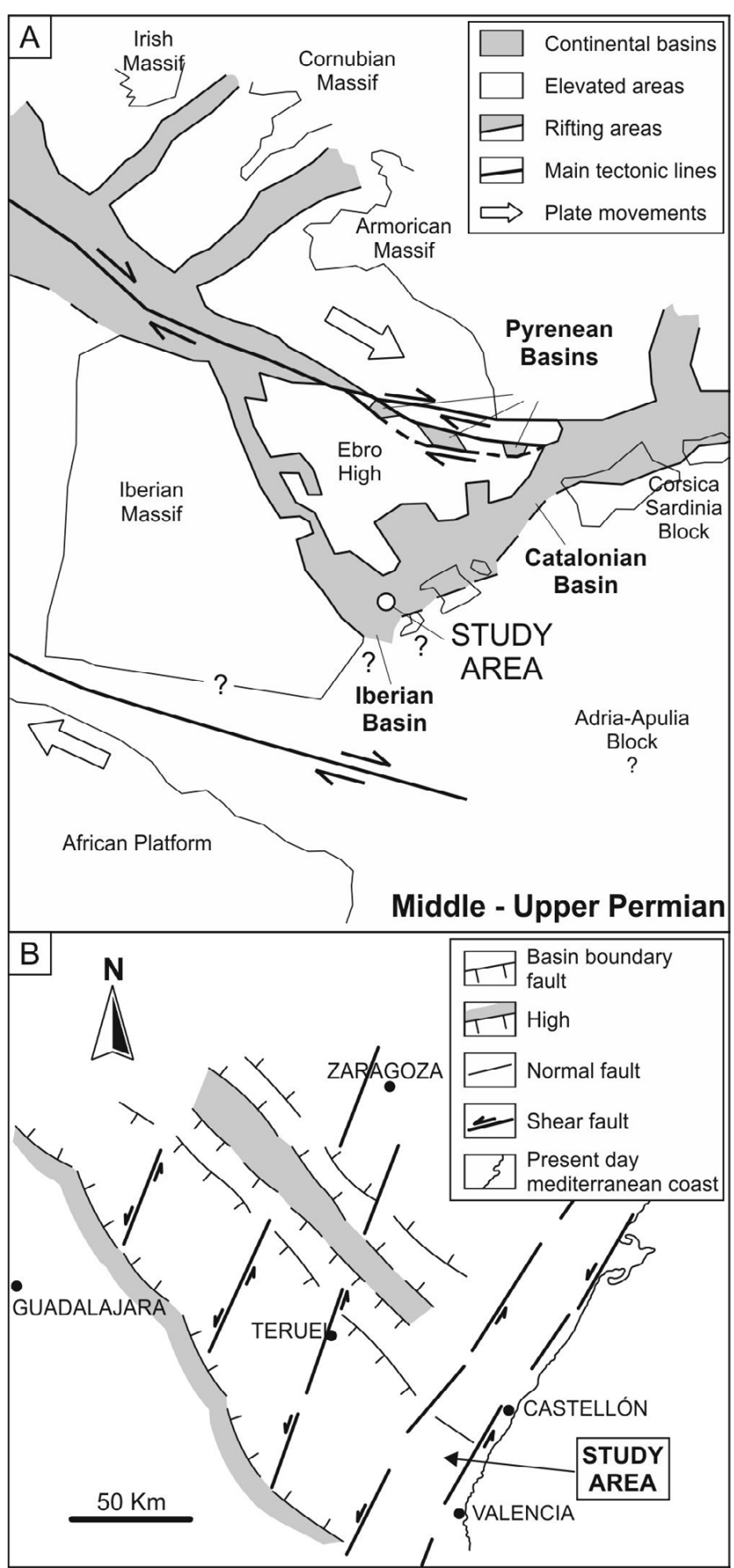

Fig. 3.- A- Location and paleogeographical reconstruction of the Iberian micro-plate and the western Tethys area for the Middle-Upper Permian showing the main rift systems and the connections between them. The location of the studied section is shown. B- Paleotectonic sketch of the Iberian Basin during the Upper Permian - Early Triassic and reconstruction of the extensional faults during the Upper Permian. Note the two main NW-SE and SW-NE thrust systems. Modified from Arche and López-Gómez (1996).

Fig. 3.- A- Localización y reconstrucción paleogeográfica de la microplaca de Iberia y el área del Tethys occidental para el Pérmico MedioSuperior mostrando los principales sistemas de rift y las conexiones entre ellos. Se localiza la sección estudiada. B- Esquema paleotectónico de la Cuenca Ibérica durante el Pérmico Superior - Triásico inferior y reconstrucción de las fallas extensionales durante el Pérmico Superior. Nótese los dos sistemas de cabalgamientos principales NW-SE y SW-NE. Modificado de Arche and López-Gómez (1996). ples were named after the igneous level; suffixes $-\mathrm{A},-\mathrm{B}$, etc. denote different samples from the same igneous level.

Several thin sections were studied from each sample. Eight polished thin sections were selected for mineral analyses. Mineral compositions were determined by electron microprobe at the Centro Nacional de Microscopía electronica of the Complutense University (Madrid, Spain), using a JEOL JZA-8900 M electron microprobe equipped with four wavelength dispersive spectrometers. Analyses were performed using an accelerating voltage of $15 \mathrm{kV}$ and an electron beam current of $20 \mathrm{nA}$, with a beam diameter of $5 \mu \mathrm{m}$. Elemental counting times were $10 \mathrm{~s}$ on the peak and $5 \mathrm{~s}$ on each of two background positions. Analyses were corrected for electronic interactions using a ZAF procedure.

Nine samples were selected for whole-rock analyses. They were crushed with a manganese steel jaw-crusher, milled with a Rechts Pulverisette agate mortar and sieved to $<53 \mu \mathrm{m}$ in the Complutense University (Madrid, Spain). Major and trace element concentrations were determined in the Faculty of Environmental Sciences of the Castilla-La Mancha University (Toledo, Spain). The samples were analysed by an ICP-AES ICAP 6500 ThermoElectron for major elements and an ICP-MS XThermoElectronSeries II for trace elements. Solutions were prepared from $0.25 \mathrm{~g}$ of each sample fluxed with $0.5 \mathrm{~g}$ of Li-metaborate and dissolved in $100 \mathrm{ml} \mathrm{HNO}_{3} 1 \mathrm{~N}$ and 3 drops of HF. Five standard reference materials provided by the US Geological Survey were used for external calibration; internal calibration of the equipment was carried out before the measurements.

Five samples were selected for isotope analyses. ${ }^{87} \mathrm{Rb} /{ }^{86} \mathrm{Sr},{ }^{87} \mathrm{Sr} /{ }^{86} \mathrm{Sr},{ }^{147} \mathrm{Sm} /{ }^{144} \mathrm{Nd}$ and ${ }^{143} \mathrm{Nd} /{ }^{144} \mathrm{Nd}$ isotopic ratios were determined at the Geochronology and Isotope Geochemistry Centre of the Complutense University (Madrid, Spain) on an automated Multicollector VG Sector 54 Mass Spectrometer. Samples were first decomposed in $5 \mathrm{ml} \mathrm{HF}$ and $2 \mathrm{ml} \mathrm{HNO}_{3}$ in Teflon digestion bombs heated for 48 hours at $120{ }^{\circ} \mathrm{C}$ and finally in $2.5 \mathrm{~N}$ $\mathrm{HCl}$. Concentrations of $\mathrm{Rb}$ and $\mathrm{Sr}$ as well as $\mathrm{Rb} / \mathrm{Sr}$ atomic ratios were determined by X-ray fluorescence spectrometry at the X-Ray Diffraction Centre of the Complutense University (Madrid, Spain), following the methods of Pankhurst and O'Nions (1973). Sm and Nd were determined by isotope dilution using spikes enriched in ${ }^{149} \mathrm{Sm}$ and ${ }^{150} \mathrm{Nd}$. Ion exchange techniques were used to separate the elements for isotopic analysis. Sr and REE were separated using a Dovex AG-50x12 cation exchange resin. Errors are quoted throughout as two standard deviations from measured or calculated values. Analytical uncertainties are estimated to be $0.01 \%$ for ${ }^{87} \mathrm{Sr} /{ }^{86} \mathrm{Sr}, 0.006 \%$ for ${ }^{143} \mathrm{Nd} /{ }^{144} \mathrm{Nd}, 1 \%$ for ${ }^{87} \mathrm{Rb} /{ }^{86} \mathrm{Sr}$, and $0.1 \%{ }^{147} \mathrm{Sm} /{ }^{144} \mathrm{Nd}$. 
Replicate analyses of the NBS-987 Sr-isotope standard yielded an average ${ }^{87} \mathrm{Sr} /{ }^{86} \mathrm{Sr}$ ratio of $0.710262 \pm 0.00007$ $(n=7)$ and La Jolla Nd-isotope standard yielded an average ${ }^{143} \mathrm{Nd} /{ }^{144} \mathrm{Nd}$ ratio of $0.511845 \pm 0.00003(\mathrm{n}=12)$.

${ }^{40} \mathrm{Ar} /{ }^{39} \mathrm{Ar}$ dating was carried out at the Institut für Erd- und Umweltwissenschaften (Potsdam University). Although plagioclase was the only K-rich phase in the rocks, it could not be used given the small size of the crystals. Therefore, leached and unleached whole-rock

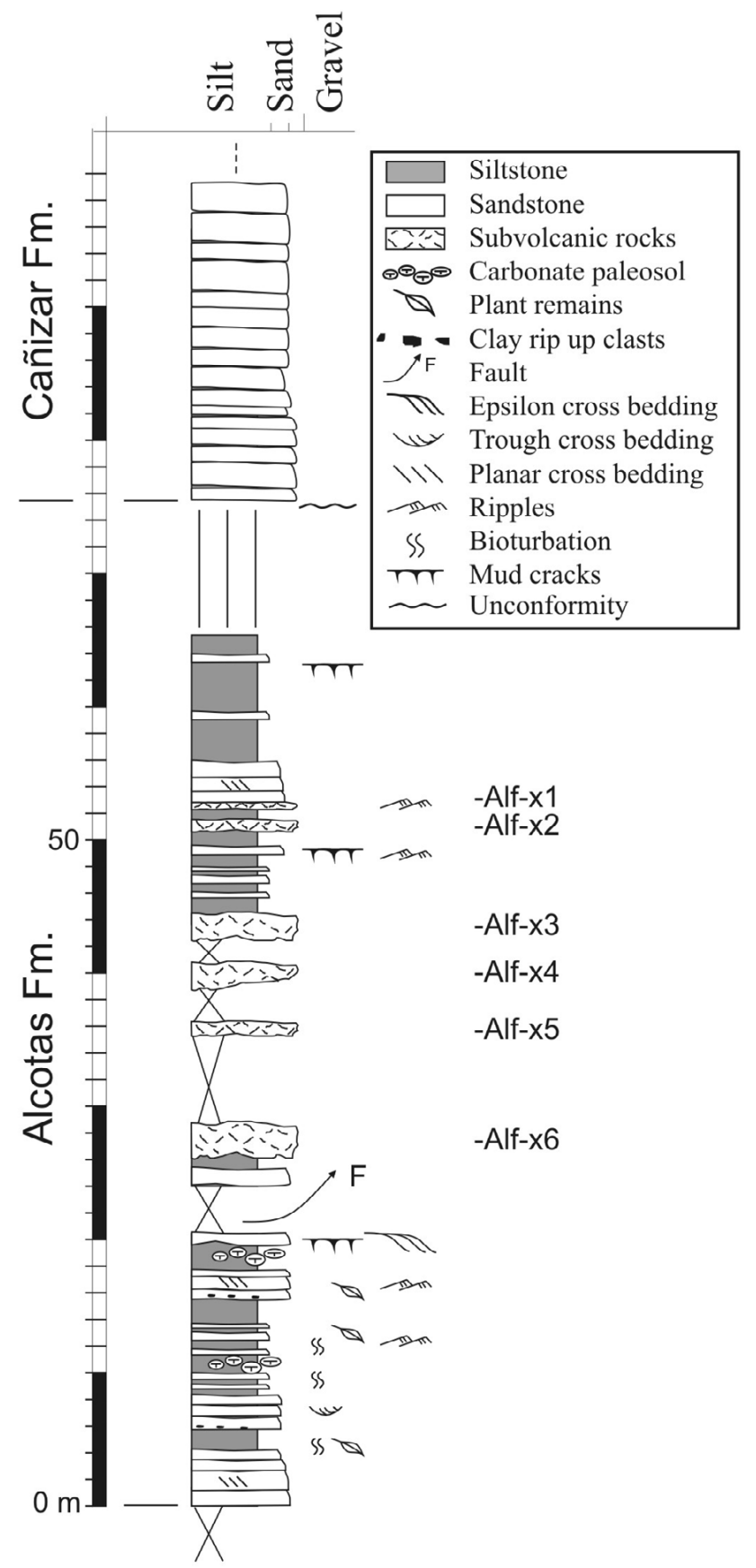

Fig. 4.- Section of the Alcotas Formation at the Alfondeguilla area (Castellón province).

Fig. 4.- Columna estratigráfica de la Formación Alcotas en la zona de Alfondeguilla (Provincia de Castellón). samples were prepared. However, no reliable ages were obtained from the experiments (neither plateaus nor isochrones could be defined), probably due to the high degree of alteration of the samples.

Data treatment was performed with "ad-hoc" built spreadsheets. Mineral abbreviations in the tables and figures are according to Whitney and Evans (2010).

\section{Petrography}

The studied samples present a primary mineral assemblage composed of plagioclase (70-80 vol. \%), clinopyroxene (3-15 vol. \%), pseudomorphosed olivine, opaque minerals (3-7 vol. \%) and accessory apatite. They generally show a subophitic to glomeroporphyritic microstructure (Fig. 6), defined by mm-sized prismatic plagioclase crystals. Olivine constitutes subidiomorphic phenocrysts completely replaced by secondary assemblages including chlorite and opaque minerals. Clinopyroxene and primary opaque minerals appear as subidiomorphic microphenocrysts. Microcrysts (mainly plagioclase and opaque minerals) are widely altered to calcite and chlorite and vesicles are filled with calcite. ALFx5 and ALFx6 levels show the highest contents in olivine and clinopyroxene.

Two xenocrysts have been recognised in the studied samples. ALFx3 contains a rounded quartz xenocryst, 6 $\mathrm{mm}$ long, unzoned, which presents a resorption rim of $0.4 \mathrm{~mm}$. Besides, ALFx 5 shows an andalusite xenocryst (Fig. 6B), $1 \mathrm{~cm}$ long, also unzoned, with a corroded and darkened rim.

\section{Geochemistry}

\subsection{Mineral chemistry}

Mineral compositions were determined for clinopyroxene, plagioclase, opaque minerals, apatite and the andalusite xenocryst (Table 1). Olivine is completely replaced by secondary minerals in all the samples, so its original composition could not be determined.

Clinopyroxene compositions were measured in samples ALFx5 and ALFx6. According to Morimoto et al. (1988), clinopyroxene is classified as augite (Fig. 7A, Table 1). Clinopyroxene compositions do not show clear differentiation trends with decreasing $\mathrm{mg}^{*}$ : $\mathrm{Mg}$ / $\left(\mathrm{Mg}+\mathrm{Fe}^{2+}+\mathrm{Fe}^{3+}+\mathrm{Mn}\right)$ per formula unit, p.f.u., where $\mathrm{Fe}^{3+}$ is calculated according to Droop (1987). $\mathrm{SiO}_{2}$ values are high (50.74-52.95 wt. \%), $\mathrm{Al}_{2} \mathrm{O}_{3}$ values are low (1.163.78 wt. \%), $\mathrm{TiO}_{2}$ values are moderate $(0.54-1.06$ wt. \%), $\mathrm{Na}_{2} \mathrm{O}$ are low $\left(0.18-0.51\right.$ wt. \%) and $\mathrm{Al}^{\mathrm{VI}}$ p.f.u. values are low (up to 0.06 ). The compositions plot in the subalkaline 

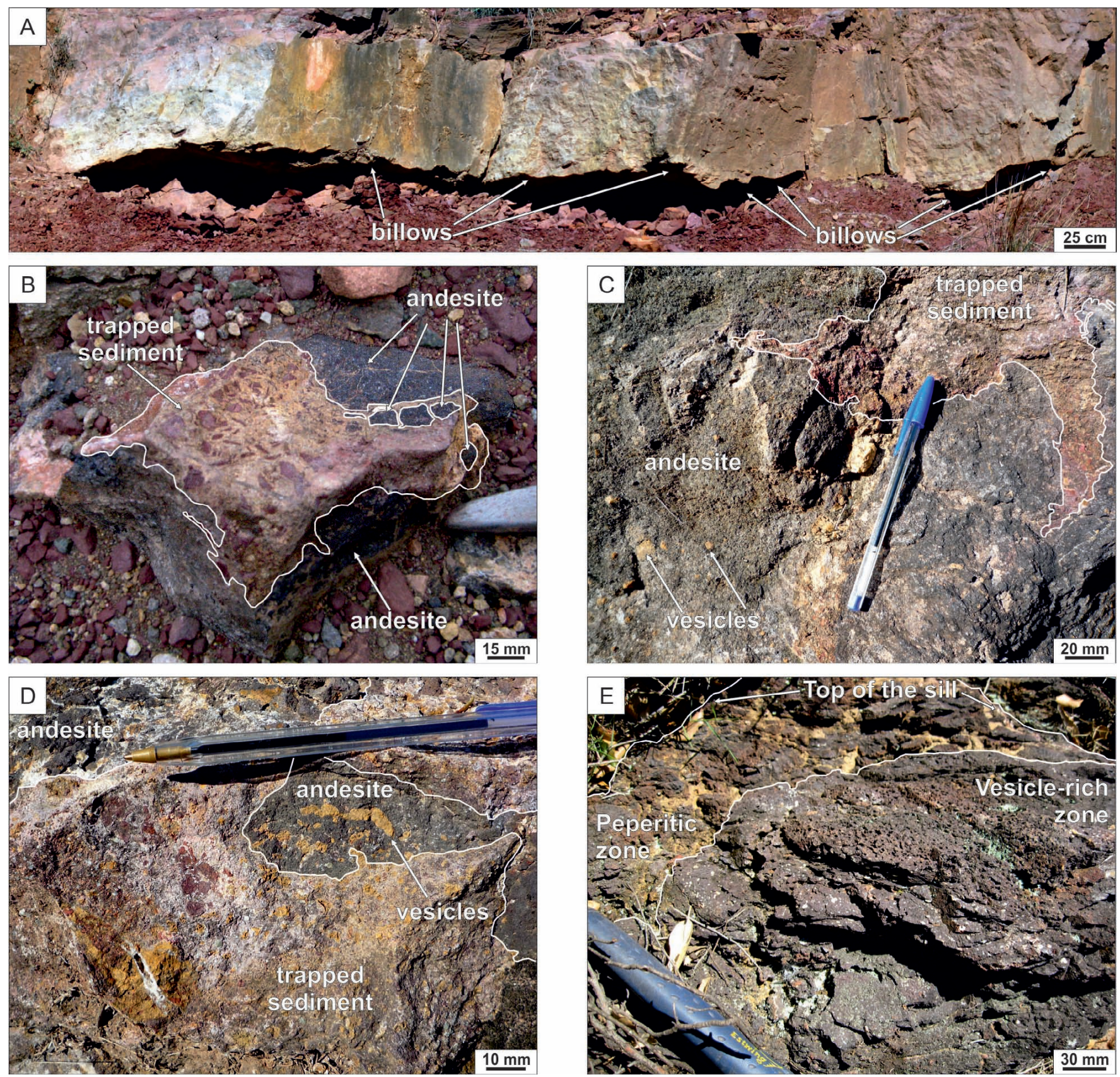

Fig. 5.- Field photographs of the igneous levels in the Alfondeguilla section. A- ALFx5 level with irregular (billowed) margins. B- Trapped sediments inside a block of andesite. C- Vesicles and trapped sediments in level ALFx6. D- Vesicles and trapped sediments in level ALFx5. E- Upper margin of the ALFx4 level, with peperites and vesicles.

Fig. 5.- Fotografías de campo de los niveles ígneos de la columna de Alfondeguilla. A- Nivel ALFx5, con contactos irregulares ("billows"). B- Sedimentos atrapados en un bloque suelto de andesita. C- Vesículas y sedimentos atrapados en el nivel ALFx6. D- Vesículas y sedimentos atrapados en el nivel ALFx5. E- Contacto superior del nivel ALFx4, en el que se desarrollan peperitas y las vesículas son abundantes.

field defined by Leterrier et al. (1982; Fig. 7B).

Plagioclase was analysed in samples ALFx2, ALFx4, ALFx5 and ALFx6, yielding compositions which vary from $\mathrm{An}_{65}$ to $\mathrm{An}_{6}$ (Table 1). Most of them are classified as labradorite and andesine (Fig. 7C). As their content in the anorthite molecule decreases, they become progressively enriched in the orthoclase molecule. Plagioclase from ALFx2 shows the most Ca-rich compositions $\left(\mathrm{An}_{65}{ }^{-}\right.$ $\mathrm{An}_{49}$ ), whilst plagioclase from ALFx6 is the most evolved
$\left(\mathrm{An}_{59}-\mathrm{An} \mathrm{n}_{6}\right)$.

Opaque minerals from ALFx2, ALFx4, ALFx5 and ALFx 6 are classified as ilmenite. Their compositions vary from 46.61 to 62.63 wt. $\% \mathrm{TiO}_{2}$ and from 32.72 to 44.81 wt. \% FeO. Apatite (analysed in ALFx2 and ALFx5) is F-rich. The andalusite xenocryst displays a homogeneous composition $\left(\mathrm{SiO}_{2}\right.$ 36.24-36.91 and $\mathrm{Al}_{2} \mathrm{O}_{3}$ 62.38-62.95 wt. \%), with $\mathrm{FeO}_{\mathrm{t}}$ contents up to 0.27 wt. \%. 

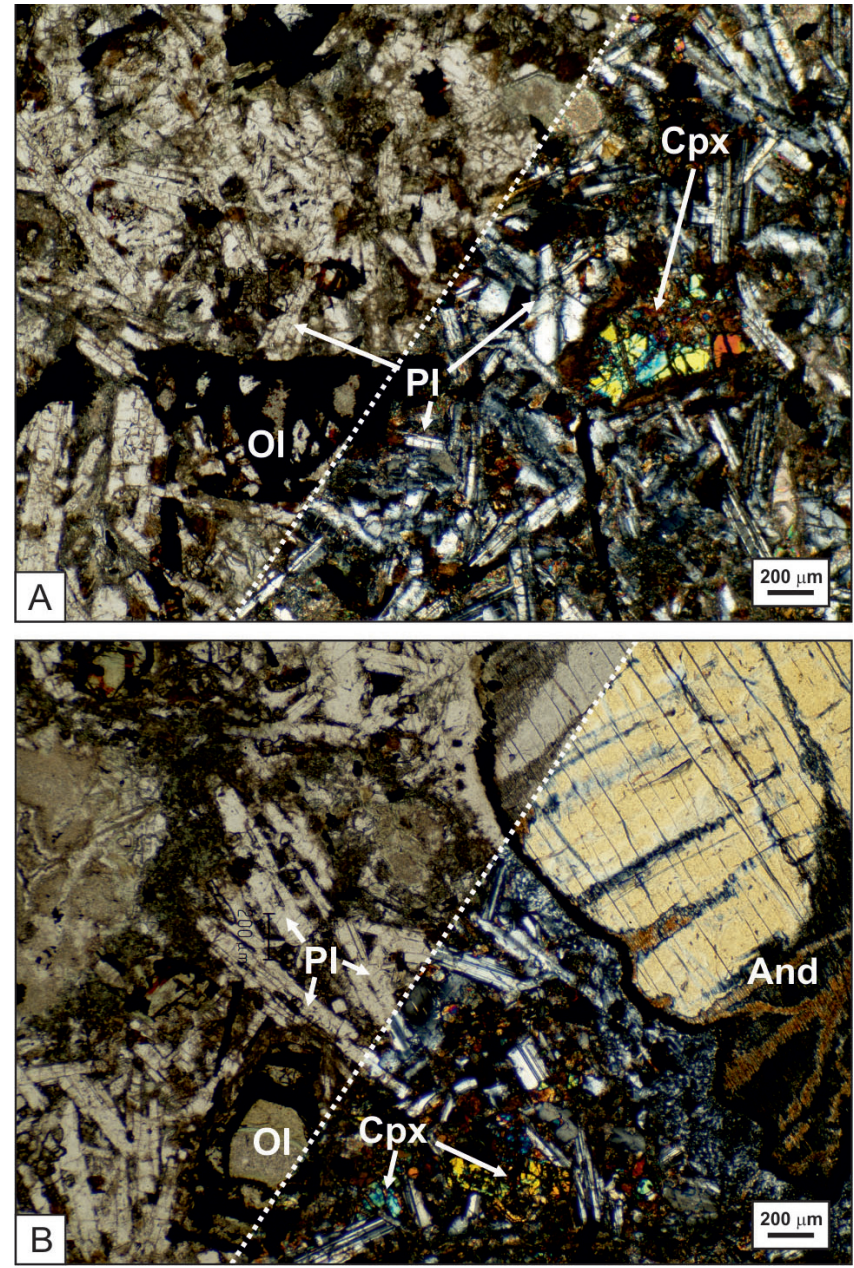

Fig. 6.- Thin section photomicrographs (plane- and cross-polarised transmitted light). A- ALFx5 level, showing the predominant subophitic microstructure defined by plagioclase prismatic crystals, with pseudomorphed olivine and clinopyroxene microphenocrysts set in a fine grained groundmass. B- Andalusite xenocryst in ALFx5 level.

Fig. 6.- Microfotografías en lámina delgada (luz transmitida con polarización paralela y cruzada). A- Nivel ALFx5, mostrando textura subofítica definida por cristales prismáticos de plagioclasa, con pseudomorfos de olivino y microfenocristales de clinopiroxeno en una mesostasia de tamaño cristalino fino. B- Xenocristal de andalucita en el nivel ALFx5.

\subsection{Whole-rock chemistry}

Three of the intrusions (ALFx2, ALFx5 and ALFx6) were selected for whole-rock analyses, including major and trace elements and $\mathrm{Sr}$ and $\mathrm{Nd}$ isotopes; samples from ALFx3 and ALFx4 were rejected due to their high alteration degree.

All the rocks show similar compositions. According to their elemental concentrations, they are classified as low$\mathrm{K}$ basaltic andesites (Fig. 8A) and alkali basalts (Fig. 8B). The calculated CIPW norm indicates they are quartz-, hypersthene- and corundum-normative. The presence of hypersthene and corundum in the norm indicates a high $\mathrm{Al}_{2} \mathrm{O}_{3}$ content in the magma, which is also recognised in the rock analyses $\left(\mathrm{Al}_{2} \mathrm{O}_{3} 14.33-14.74\right.$ wt. \%, Table 2), in agreement with the high modal proportion of plagioclase in these rocks.

The variation of $\mathrm{Mg} \#$ (molar ratio $\mathrm{MgO} /(\mathrm{MgO}+\mathrm{FeO})$ ) vs. other meaningful elements (Fig. 9) draws poorly defined differentiation trends, mainly due to the high resemblance among the different samples. In detail, ALFx 5 presents the highest Mg\# values, representing the least evolved level. However, none of the analysed samples (Table 2) presents compositional features typical of primitive magmas in equilibrium with their mantle source (in such cases $\mathrm{MgO}>11$ wt. \%, $\mathrm{Mg} \#>0.6-0.7, \mathrm{Cr}>500$ 1000 ppm and $\mathrm{Ni}>200-500$ ppm; Frey et al., 1978). On the other hand, ALFx2 shows the lowest concentrations in $\mathrm{TiO}_{2}, \mathrm{P}_{2} \mathrm{O}_{5}$ and $\mathrm{Na}_{2} \mathrm{O}$ and the highest $\mathrm{CaO}$ values (Fig. 9A-E), in agreement with the higher anorthite contents in its plagioclase (Fig. 7C). Indeed, ALFx5 and ALFx6 can be compositionally grouped (Fig. 9), in agreement with their higher proportion of ferromagnesian minerals (olivine and clinopyroxene) compared to ALFx2. Loss On Ignition (LOI) values (Table 2) are higher for ALFx2 than for ALFx5 and ALFx6, probably related to the high alteration degree shown by plagioclase, more abundant in ALFx2. The primitive mantle-normalised incompatible ratios $(\mathrm{La} / \mathrm{Lu})_{\mathrm{N}}$ are moderately high $(10.12-13.30$; Table 2) and decrease with Mg\# (Fig. 9F).

Primitive mantle-normalised multielemental patterns are rather similar to each other (Fig. 10). The most incompatible elements are up to 100 times enriched over primitive mantle. The samples present $\mathrm{Rb}-\mathrm{Ba}$ and $\mathrm{K}$ negative anomalies and $\mathrm{Nb}$-Ta enrichments. Furthermore, Sm and Ti are slightly depleted, $\mathrm{P}$ shows a small positive anomaly and $\mathrm{Pb}$ displays a relative variability. These features are very similar to those of enriched mantle sources with a HIMU component (Hoffman, 1997).

Isotopic initial ratios of ${ }^{87} \mathrm{Sr} /{ }^{86} \mathrm{Sr}$ and ${ }^{143} \mathrm{Nd} /{ }^{144} \mathrm{Nd}$ (Table 2) vary from 0.7035 to 0.7037 and from 0.5124 to 0.5127 , respectively. These ratios are $\mathrm{Nd}$-enriched $(\varepsilon \mathrm{Nd}$ ranges from +1.7 to +8.3$)$ and $\mathrm{Sr}$-depleted $(\varepsilon \mathrm{Sr}$ ranges from -6.8 to -9.2) compared to the Bulk Silicate Earth (BSE) (Fig. 11). These values are similar to the enriched HIMU mantle component of Zindler and Hart (1986). The calculated T-depleted mantle (DM) model ages are between 0.37 and $0.98 \mathrm{Ga}$. This wide range of model ages is related to the variability in the ${ }^{143} \mathrm{Nd} /{ }^{144} \mathrm{Nd}$ values.

\section{Discussion}

\subsection{Emplacement of the magma}

The different igneous levels recognised in the Alfondeguilla section emplaced along sedimentary bedding 


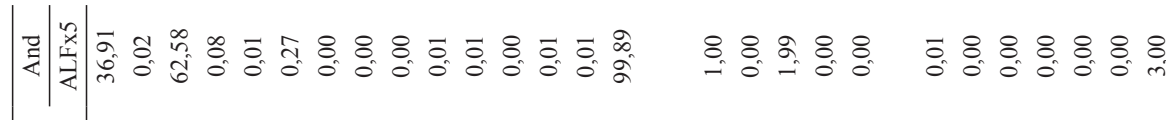

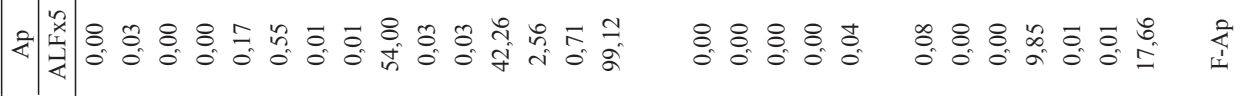

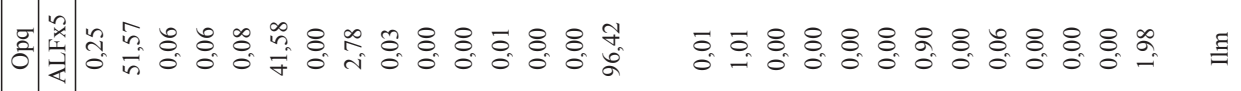

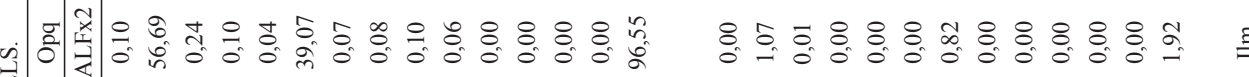

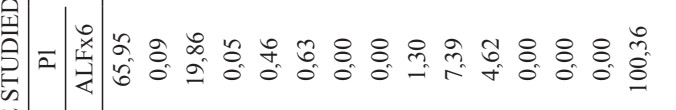

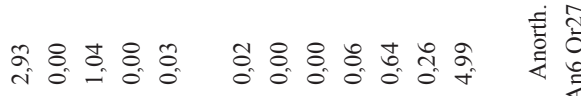

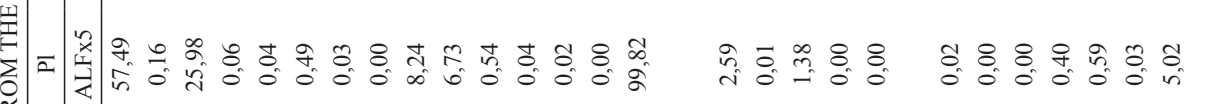

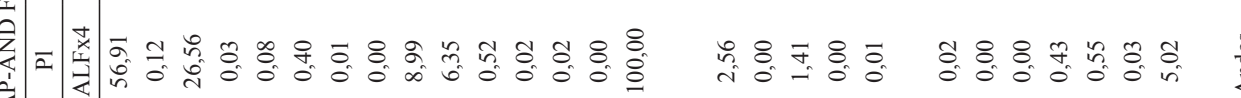

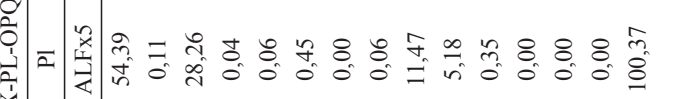

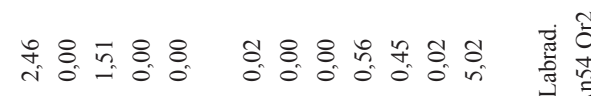

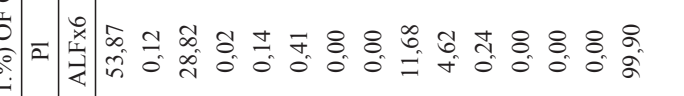

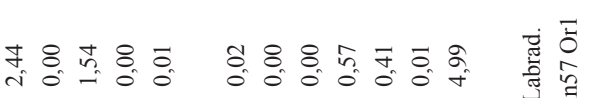

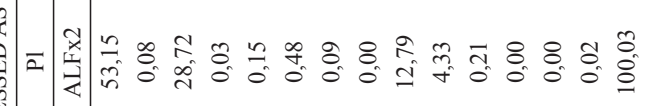

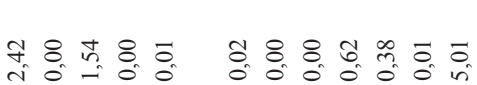

要

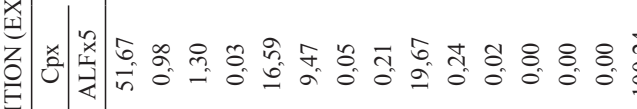

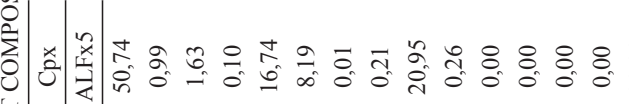

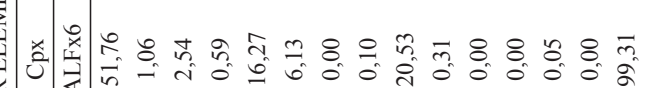

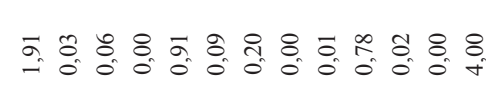

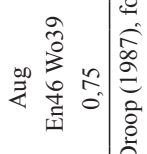

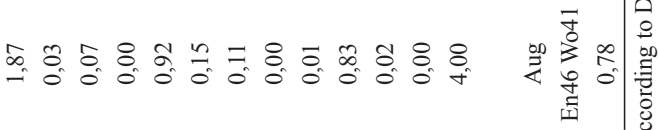

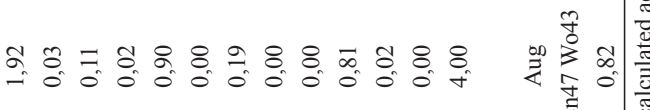

焉

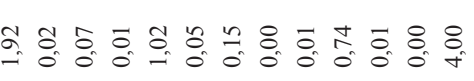

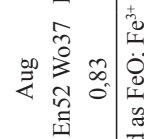

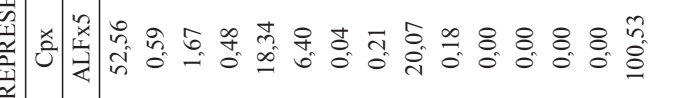
D.

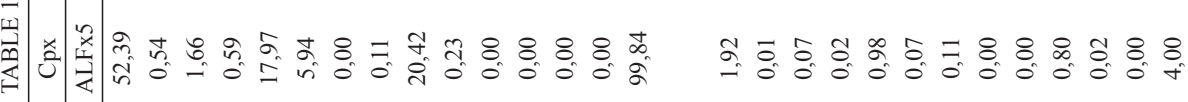

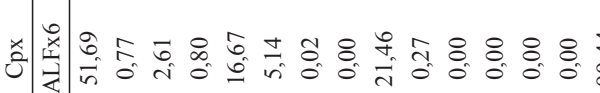

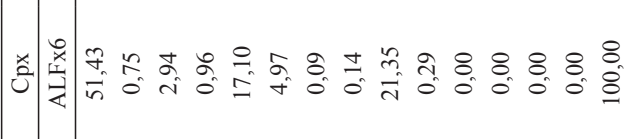

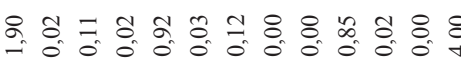
竞

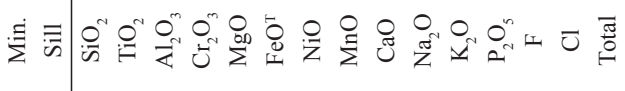

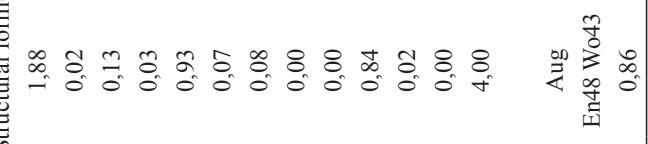

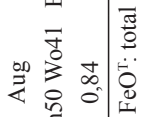

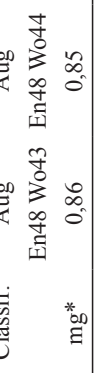


TABLE 2.- WHOLE ROCK AND ISOTOPIC Sr-Nd COMPOSITION OF ALFONDEGUILLA SILLS.

\begin{tabular}{|c|c|c|c|c|c|c|c|c|c|}
\hline Sample & ALFx2A & ALFx2B & ALFx2C & ALFx2D & ALFx5A & ALFx5B & ALFx5C & ALFx6A & ALFx6B \\
\hline $\mathrm{SiO}_{2}$ & 51,77 & 52,91 & 52,85 & 52,26 & 54,44 & 54,07 & 54,62 & 54,43 & 54,51 \\
\hline $\mathrm{TiO}_{2}$ & 1,71 & 1,61 & 1,68 & 1,67 & 1,78 & 1,74 & 1,74 & 1,74 & 1,74 \\
\hline $\mathrm{Al}_{2} \mathrm{O}_{3}$ & 14,33 & 14,53 & 14,62 & 14,43 & 14,73 & 14,55 & 14,74 & 14,52 & 14,58 \\
\hline $\mathrm{Fe}_{2} \mathrm{O}_{3 \mathrm{t}}$ & 9,85 & 10,84 & 9,94 & 10,04 & 9,91 & 10,20 & 10,78 & 11,18 & 11,37 \\
\hline MnO & 0,09 & 0,09 & 0,09 & 0,10 & 0,06 & 0,10 & 0,09 & 0,08 & 0,11 \\
\hline MgO & 6,57 & 6,22 & 6,57 & 6,39 & 7,39 & 7,31 & 6,92 & 6,65 & 7,02 \\
\hline $\mathrm{CaO}$ & 6,91 & 6,78 & 6,74 & 6,87 & 4,74 & 6,39 & 6,20 & 5,59 & 6,49 \\
\hline $\mathrm{Na}_{2} \mathrm{O}$ & 2,46 & 2,52 & 2,61 & 2,58 & 3,29 & 3,19 & 3,30 & 2,93 & 3,03 \\
\hline $\mathrm{K}_{2} \mathrm{O}$ & 0,64 & 0,60 & 0,66 & 0,64 & 0,67 & 0,69 & 0,73 & 0,42 & 0,51 \\
\hline $\mathbf{P}_{2} \mathbf{O}_{5}$ & 0,43 & 0,43 & 0,42 & 0,42 & 0,50 & 0,51 & 0,52 & 0,47 & 0,48 \\
\hline LOI & 4,95 & 3,96 & 3,72 & 4,32 & 1,57 & 1,24 & 1,11 & 2,12 & 0,88 \\
\hline mg* & 0,60 & 0,57 & 0,60 & 0,59 & 0,63 & 0,62 & 0,59 & 0,58 & 0,58 \\
\hline Total & 99,71 & 100,49 & 99,90 & 99,72 & 99,08 & 99,99 & 100,75 & 100,13 & 100,72 \\
\hline $\mathbf{R b}$ & 6,48 & 5,31 & 6,20 & 5,81 & 13,16 & 13,33 & 15,38 & 7,88 & 12,49 \\
\hline Cs & 0,95 & 1,03 & 1,27 & 0,89 & 2,28 & 2,90 & 2,59 & 2,53 & 3,03 \\
\hline $\mathrm{Sr}$ & 419,15 & 430,51 & 420,88 & 402,24 & 399,16 & 441,29 & 475,23 & 361,60 & 419,39 \\
\hline Ba & 152,24 & 152,99 & 153,37 & 146,42 & 165,88 & 167,37 & 222,12 & 143,86 & 175,30 \\
\hline $\mathbf{V}$ & 144,89 & 156,56 & 163,85 & 165,53 & 189,72 & 165,22 & 162,98 & 179,07 & 169,79 \\
\hline $\mathrm{Cr}$ & 353,68 & 402,17 & 402,95 & 408,64 & 448,40 & 405,35 & 401,90 & 424,24 & 398,36 \\
\hline Co & 37,82 & 40,64 & 40,10 & 42,38 & 45,88 & 41,65 & 40,71 & 46,01 & 44,13 \\
\hline $\mathrm{Ni}$ & 174,49 & 190,53 & 184,73 & 189,12 & 213,60 & 187,18 & 183,47 & 225,80 & 210,85 \\
\hline $\mathrm{Cu}$ & 53,75 & 56,75 & 43,48 & 36,88 & 21,96 & 14,20 & 11,88 & 23,31 & 12,97 \\
\hline $\mathbf{Y}$ & 22,70 & 23,79 & 21,10 & 20,78 & 19,23 & 22,49 & 23,37 & 20,38 & 23,73 \\
\hline $\mathrm{Nb}$ & 39,54 & 40,49 & 41,33 & 41,38 & 54,28 & 50,60 & 51,57 & 47,05 & 46,37 \\
\hline Ta & 3,23 & 3,13 & 3,06 & 2,87 & 3,45 & 3,69 & 3,88 & 3,03 & 3,39 \\
\hline $\mathrm{Zr}$ & 146,01 & 143,17 & 137,86 & 135,31 & 152,60 & 159,98 & 167,90 & 141,87 & 155,47 \\
\hline Hf & 3,50 & 3,40 & 3,29 & 3,21 & 3,47 & 3,65 & 3,78 & 3,26 & 3,58 \\
\hline Mo & 1,87 & 1,99 & 1,86 & 1,64 & 2,14 & 2,32 & 2,45 & 1,94 & 2,26 \\
\hline $\mathbf{P b}$ & 5,78 & 4,36 & 5,38 & 4,86 & 4,22 & 3,02 & 3,76 & 4,08 & 2,69 \\
\hline $\mathbf{U}$ & 1,32 & 1,22 & 1,21 & 1,17 & 1,37 & 1,50 & 1,56 & 1,16 & 1,28 \\
\hline Th & 4,28 & 4,07 & 3,91 & 3,80 & 4,22 & 4,67 & 4,83 & 3,85 & 4,29 \\
\hline $\mathbf{L a}$ & 25,80 & 25,35 & 24,31 & 23,71 & 25,68 & 28,48 & 29,64 & 23,80 & 27,00 \\
\hline $\mathrm{Ce}$ & 47,28 & 46,58 & 44,52 & 43,38 & 46,64 & 51,52 & 53,71 & 43,46 & 49,28 \\
\hline Pr & 5,46 & 5,39 & 5,13 & 4,98 & 5,20 & 5,83 & 6,08 & 4,92 & 5,66 \\
\hline Nd & 23,12 & 22,78 & 21,76 & 21,18 & 21,81 & 24,23 & 25,23 & 20,68 & 23,77 \\
\hline $\mathrm{Sm}$ & 5,38 & 5,44 & 5,05 & 5,01 & 4,85 & 5,45 & 5,71 & 4,80 & 5,51 \\
\hline $\mathbf{E u}$ & 1,63 & 1,73 & 1,68 & 1,66 & 1,78 & 1,69 & 1,79 & 1,62 & 1,71 \\
\hline Gd & 5,30 & 5,50 & 5,12 & 4,96 & 4,84 & 5,41 & 5,70 & 4,82 & 5,60 \\
\hline $\mathbf{T b}$ & 0,84 & 0,88 & 0,78 & 0,76 & 0,74 & 0,83 & 0,86 & 0,74 & 0,86 \\
\hline Dy & 4,46 & 4,63 & 4,21 & 4,04 & 3,81 & 4,42 & 4,52 & 3,94 & 4,59 \\
\hline Ho & 0,84 & 0,86 & 0,78 & 0,76 & 0,70 & 0,82 & 0,84 & 0,74 & 0,86 \\
\hline $\mathbf{E r}$ & 2,08 & 2,12 & 1,90 & 1,85 & 1,71 & 2,00 & 2,06 & 1,81 & 2,07 \\
\hline Tm & 0,29 & 0,29 & 0,27 & 0,27 & 0,25 & 0,29 & 0,30 & 0,25 & 0,30 \\
\hline $\mathbf{Y b}$ & 1,68 & 1,64 & 1,56 & 1,52 & 1,36 & 1,58 & 1,66 & 1,46 & 1,68 \\
\hline $\mathbf{L u}$ & 0,26 & 0,25 & 0,23 & 0,23 & 0,20 & 0,25 & 0,25 & 0,22 & 0,25 \\
\hline $\mathbf{N b} / \mathbf{Y}$ & 1,74 & 1,70 & 1,96 & 1,99 & 2,82 & 2,25 & 2,21 & 2,31 & 1,95 \\
\hline$(\mathrm{La} / \mathrm{Lu})_{\mathrm{N}}$ & 10,52 & 10,54 & 10,89 & 10,60 & 13,30 & 12,07 & 12,46 & 11,51 & 11,04 \\
\hline $\mathbf{T i} / \mathbf{V}$ & 70,64 & 61,62 & 61,53 & 60,54 & 56,31 & 63,21 & 64,12 & 58,24 & 61,35 \\
\hline${ }^{87} \mathbf{R b} /{ }^{86} \mathbf{S r}$ & & 0,00886 & 0,00992 & & & 0,02252 & 0,02548 & & 0,02345 \\
\hline${ }^{87} \mathrm{Sr} /{ }^{86} \mathrm{Sr}$ & & 0,70370 & 0,70374 & & & 0,70363 & 0,70375 & & 0,70380 \\
\hline err. $\mathrm{Sr}$ & & 6 & 5 & & & 7 & 6 & & 6 \\
\hline${ }^{87} \mathrm{Sr} /{ }^{86} \mathrm{Sr}_{(267)}$ & & 0,70367 & 0,70370 & & & 0,70354 & 0,70365 & & 0,70371 \\
\hline$\varepsilon S r$ & & $-7,32$ & $-6,85$ & & & $-9,16$ & $-7,61$ & & $-6,79$ \\
\hline${ }^{147} \mathrm{Sm} /{ }^{144} \mathrm{Nd}$ & & 0,13518 & 0,13331 & & & 0,12934 & 0,12941 & & 0,13260 \\
\hline${ }^{143} \mathrm{Nd} /{ }^{144} \mathrm{Nd}$ & & 0,51280 & 0,51295 & & & 0,51261 & 0,51261 & & 0,51277 \\
\hline err. Nd & & 4 & 5 & & & 5 & 3 & & 4 \\
\hline$\varepsilon N d$ & & 5,26 & 8,31 & & & 1,69 & 1,69 & & 4,74 \\
\hline$T_{\text {DM(Ga) }}$ & & 0,68 & 0,37 & & & 0,98 & 0,98 & & 0,72 \\
\hline
\end{tabular}

Table 2.- Major element (wt.\%) and trace element (ppm) composition and isotopic ratios of selected samples from the Alfondeguilla igneous rocks. Isotopic initial ratios were recalculated to $267 \mathrm{Ma}$ (Debon and Zimmerman, 1993; Galé, 2005).

Tabla 2.- Composición en elementos mayores (\% en peso) y traza (ppm) y relaciones isotópicas de las muestras seleccionadas de las rocas ígneas de Alfondeguilla. Las relaciones isotópicas iniciales se han calculado a 267 Ma (Debon y Zimmerman, 1993; Galé, 2005). 

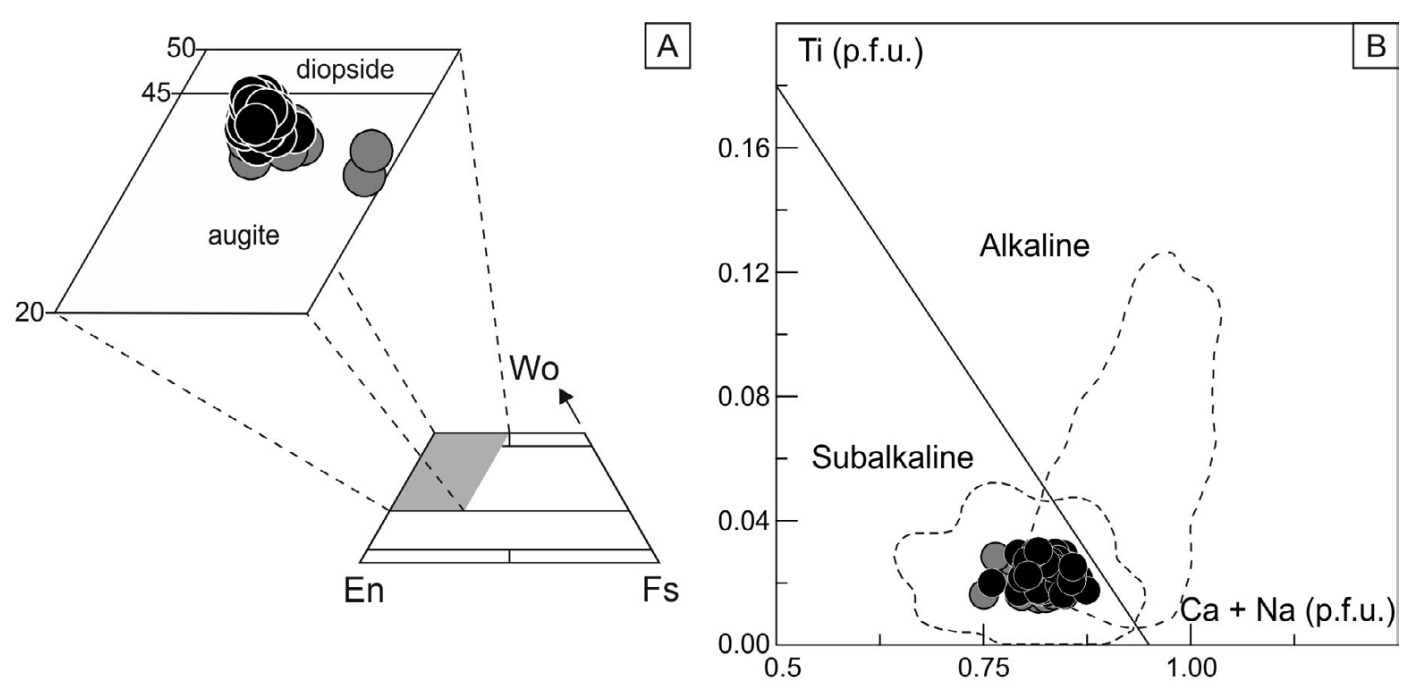

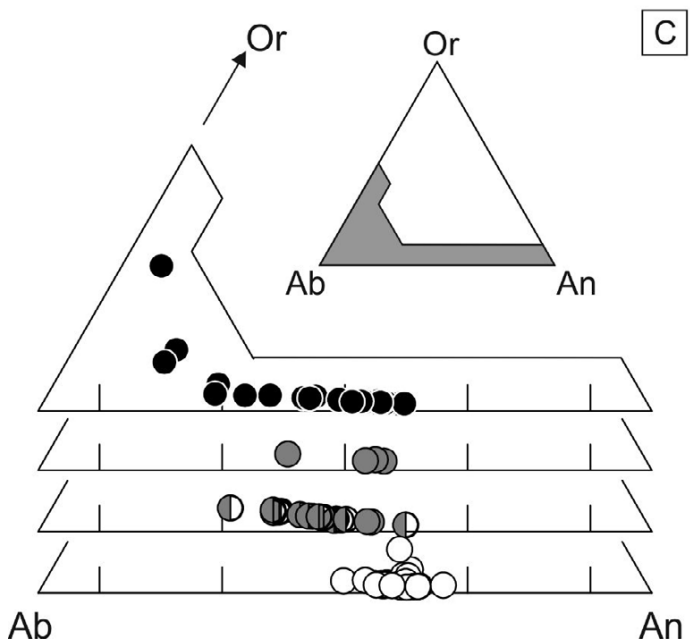

planes, so they can be considered sill-like structures. The levels are very close to each other, and get even closer towards the top of the sequence. Therefore, they probably belong to a single, multiple sill. This hypothesis is supported by the similar mineral and whole-rock compositions of the different analysed levels (Figs. 7, 8, 9, 10). Consequently, the multiple Alfondeguilla sill is a complex consisting of at least six individual levels, which become thinner towards the top.

The formation of a multiple sill instead of a large, homogenous magma body depends on the injection frequency and the rate of solidification. If the first igneous level has already solidified and perhaps cooled down to a temperature similar to that of the country rock, then the next sill to form will remain a separate unit, even if adjacent, and the initial sill has no chance of developing into a magma chamber (Burchardt and Gudmundsson, 2008).

The heat transfer approximation by Jaeger (1968) permits calculating the cooling time of the levels of the sill. For an average thickness of $1 \mathrm{~m}$ and a thermal diffusivity of $10^{-6} \mathrm{~m}^{2} / \mathrm{s}$ (Huppert and Sparks, 1980), $7 \mathrm{~h}$ after the emplacement of the magma the centre of the sill started
Fig. 7.- Mineral composition of the studied sills. A- Clinopyroxene classification diagram (Morimoto et al., 1988). BClinopyroxene compositions plotted in the $\mathrm{Ti}$ vs. $\mathrm{Ca}+\mathrm{Na}$ diagram (Leterrier et al., 1982). C- Feldspar classification diagram. ALFx6: filled black circles; ALFx5: filled grey circles; ALFx4: half-filled grey circles; ALFx2: white circles.

Fig. 7.- Composición mineral de los sill estudiados. A- Diagrama de clasificación de clinopiroxenos (Morimoto et al., 1988). B- Composiciones de clinopiroxeno representadas en el diagrama $\mathrm{Ti}$ vs. $\mathrm{Ca}+\mathrm{Na}$ (Leterrier et al., 1982). CDiagrama de clasificación del feldespato. ALFx6: círculos en negro; ALFx5: círculos en gris: ALFx4: medios círculos grises; ALFx2: círculos en blanco.

cooling; $69 \mathrm{~h}$ after the emplacement of the magma cooling was substantial at the centre of the sill and about as much heat had been lost to the country-rock as remained in the sill. Taking these calculations into account, the cooling time of each level was fast, conditioning the formation of a multiple sill.

Irregular contacts marked by wavy, billowed margins (Fig. 5A) and the development of peperites (Fig. 5E) have been described by other authors where magma has come in contact with wet, unconsolidated sediment (Befus et al., 2009; Kokelaar, 1982; Leat and Thompson, 1988; Kano, 1991; Walker, 1992; Kano, 2002; Lavine and Aalto, 2002; Németh and Martin, 2007). The fact that peperites are only recognised in ALFx4 and ALFx6 levels is probably related to the fact that they are the thickest levels (ALFx6 is more than 3 meters thick). In this situation, the magma cooling rate is significantly lower than in the other levels, allowing for the development of this type of magma-sediment interactions. Furthermore, the presence of irregular fragments of structure-less sediments inside all the igneous levels (Fig. 5B-D) supports the interaction between the magma and the unconsolidated wet 

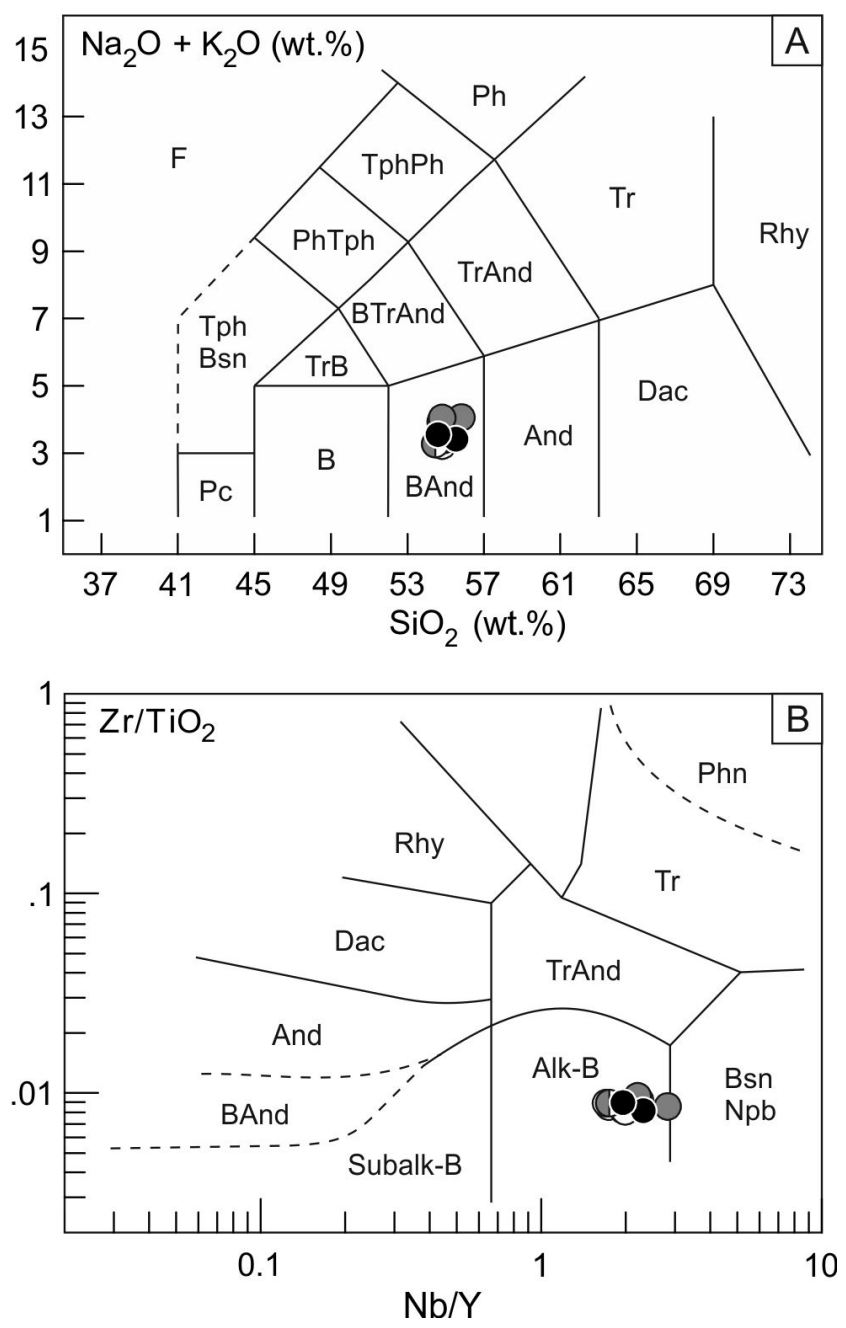

Fig. 8.- Total Alkalis vs. Silica (TAS) diagram (Le Bas et al., 1986) (A) and $\mathrm{Zr} / \mathrm{TiO}_{2}$ vs. $\mathrm{Nb} / \mathrm{Y}$ diagram (Winchester and Floyd, 1977) (B) applied to whole-rock compositions from the studied sills. ALFx6: filled black circles; ALFx5: filled grey circles; ALFx2: white circles.

Fig. 8.- Diagrama con proyección Álcalis Total vs. Sílice (TAS) (Le Bas et al., 1986) (A) y diagrama $\mathrm{Zr} / \mathrm{TiO}_{2} v s . \mathrm{Nb} / \mathrm{Y}$ (Winchester and Floyd, 1977) (B) aplicados a las composiciones de roca total de los sills estudiados. ALFx6: círculos en negro; ALFx5: círculos en gris; ALFx2: círculos en blanco.

sediments (Kokelaar, 1982).

The emplacement of the magma into unconsolidated, wet sediments agrees with the sedimentation of the Middle and Upper Parts of the Alcotas Formation in a fluvial environment under periods of humid conditions (Arche and López-Gómez, 2005; De la Horra et al., 2012; Diéguez et al., 2007).

Finally, a shallow emplacement level is inferred from the presence of vesicles (Fig. 5C-E), since low lithostatic pressures are necessary to enable the degassing of the magma (Latypov, 2003). The greater abundance of vesicles in the chilled margins of the thickest levels is also due to their slower cooling rates.

\subsection{Geochemical affinity, conditions of crystallisation and mantle source}

The identification of the geochemical affinity of the studied rocks is not straight. On the one hand, clinopyroxene has moderate Ti-contents (Table 1) and its composition is plotted within the subalkaline field defined by Leterrier et al. (1982; Fig. 7B). In addition, these rocks have low total alkalis $\left(\mathrm{Na}_{2} \mathrm{O}+\mathrm{K}_{2} \mathrm{O}\right.$ wt. \%) contents (Table 2) and, therefore, a lack of normative nepheline (Le Maitre, 2002), suggesting a subalkaline affinity. On the other hand, plagioclase compositions display a typically alkaline trend of increasing orthoclase with decreasing anorthite (Fig. 7C) and whole-rock incompatible element ratios point to an alkaline affinity $(\mathrm{Nb} / \mathrm{Y}: 1.70-2.82$; Fig. $8 \mathrm{~B}$ ). Moreover, Ti/V ratios over 50 (Table 2) are typical of alkali basalts and oceanic island basalts (Shervais, 1982). As a consequence, the affinity of the rocks should be better explained as transitional between subalkaline and alkaline. This feature is characteristic of some Middle-Upper Permian magmatisms from the western Tethys (e.g., Pyrenees, Catalonian Coastal Ranges, Corsica-Sardinia and southern France; Lago et al., 2004a; Lapierre et al., 1999; Traversa et al., 2003; Ubide et al., 2010), resulting from a transitional tectono-magmatic regime, between the Variscan compression and the Alpine extension (e.g., Bixel, 1988; Bonin, 1988; Cassinis et al., 2012).

In order to constrain the crystallisation conditions of the magma, we have applied the MELTS software (Asimow and Ghiorso, 1998; Ghiorso and Shack, 1995) to the composition of the analysed samples. The low $\mathrm{Na}_{2} \mathrm{O}$ concentrations $\left(0.18-0.51\right.$ wt. \%) and $\mathrm{Al}^{\mathrm{VI}}$ p.f.u. values (0.00-0.06) of the studied clinopyroxenes indicate a low pressure of crystallisation (e.g., Nimis, 1995), compatible with the presence of vesicles in the rocks and with the emplacement of the magma into unconsolidated sediments (see section 7.1). Accordingly, we have considered a low pressure for the calculations (100 MPa). The liquidus temperatures range from 1265 to $1198{ }^{\circ} \mathrm{C}$; compositions from the sill ALFx5 yield the highest temperatures, whereas the lowest ones correspond to sill ALFx2. In agreement with this, in ALFx5 and ALFx6 levels minerals play a different role in the fractionation process than in ALFx2, where ferromagnesian minerals are very scarce and the fractionation process was probably controlled by plagioclase. The isobaric equilibrium crystallisation model yields the following results: olivine crystallises in the first place, at $1230-1220{ }^{\circ} \mathrm{C}$; plagioclase is the predominant phase, starting to crystallise at 1110-1080 ${ }^{\circ} \mathrm{C}$; clinopyroxene (starting at $1030-1000{ }^{\circ} \mathrm{C}$ ) appears as a late phase, probably crystallising at the emplacement level. In all the cases, the model generates opaque miner- 

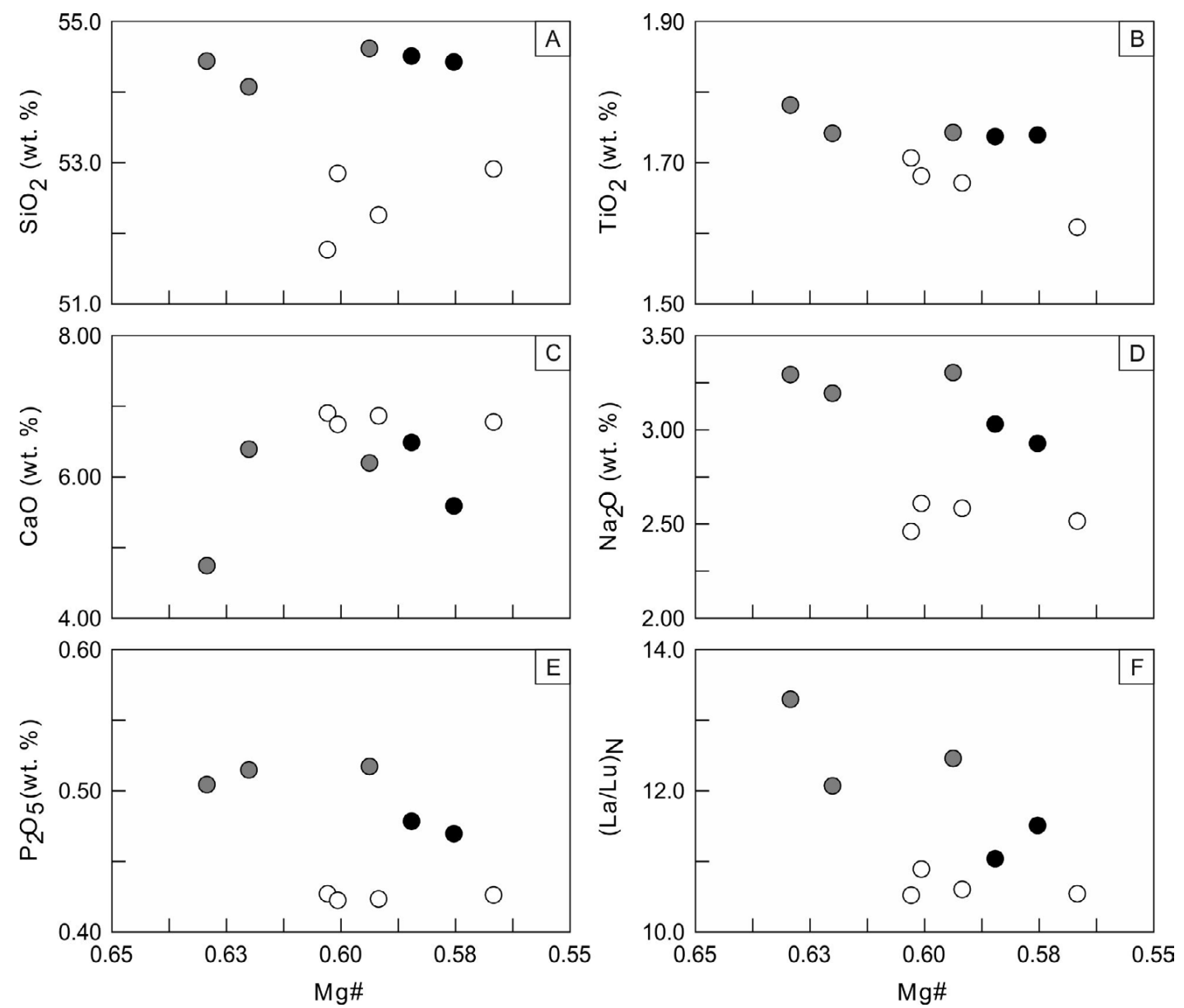

Fig. 9.- Whole-rock compositions of the studied sills plotted in bivariate diagrams vs. Mg\#. ALFx6: filled black circles; ALFx5: filled grey circles; ALFx2: white circles.

Fig. 9.- Composiciones de roca total de los sills estudiados representadas en diagramas bivariantes vs. Mg\#. ALFx6: círculos en negro; ALFx5: círculos en gris; ALFx2: círculos en blanco.

als, apatite and orthopyroxene. In general, the obtained crystallisation sequences are rather similar to the real ones observed in the studied rocks; the presence of orthopyroxene in the model (not recognised in the rocks) is probably related to the high $\mathrm{Al}_{2} \mathrm{O}_{3}$ contents of the rocks and is coherent with their normative hypersthene.

According to their relatively low $\mathrm{MgO}, \mathrm{Cr}$ and $\mathrm{Ni}$ contents, the composition of the studied rocks does not represent primitive melts in equilibrium with their mantle source. The high $\mathrm{SiO}_{2}$ and $\mathrm{Al}_{2} \mathrm{O}_{3}$ contents, resulting in normative quartz, hypersthene and corundum, point to a modification of the mantle melts en route to the emplacement level or even related to the emplacement mechanism. This hypothesis is supported by the presence of xenocrysts of quartz and andalusite with resorption textures. Besides, fragments of sediments are frequently observed inside the sill and even magma-sediment intermixtures (peperites) have been recognised in the thickest level. The addition of variable proportions of this type of felsic, peraluminous sediments would explain the anomalous enrichments in $\mathrm{SiO}_{2}$ and $\mathrm{Al}_{2} \mathrm{O}_{3}$. Trace element and isotopic $\mathrm{Sr}$ results do not support a significant crustal contamination (e.g., low and homogeneous $\varepsilon S r$ values). Therefore, modification of the melts during emplacement seems the most important mechanism.

The primitive mantle - normalised trace element contents (Fig. 10) are similar to melts of enriched mantle sources with a HIMU component. This type of source is supported by the isotopic results (Fig. 11), despite the large variability of the $\mathrm{Nd}$ isotopic ratios. The high $(\mathrm{La} / \mathrm{Lu})$ ${ }_{N}$ values of the samples (Table 2 ) are consistent with highly fractionated melts, common in enriched mantle sources.

Concerning the composition of the melting mantle source, the negative anomalies in alkali elements $(\mathrm{K}, \mathrm{Rb}$, Ba) (Fig. 10) appear to require the presence of an amphibole or phlogopite residue in this mantle source. The relative abundances of alkali elements can be used to determine which of these phases were retained in the mantle during the melting process. According to McCoy-West et al. (2010), melts in equilibrium with phlogopite are expected to present $\mathrm{Rb} / \mathrm{Sr}(>0.1)$ and $\mathrm{Ba} / \mathrm{Rb}(<20)$ ratios significantly higher and lower, respectively, than melts in 


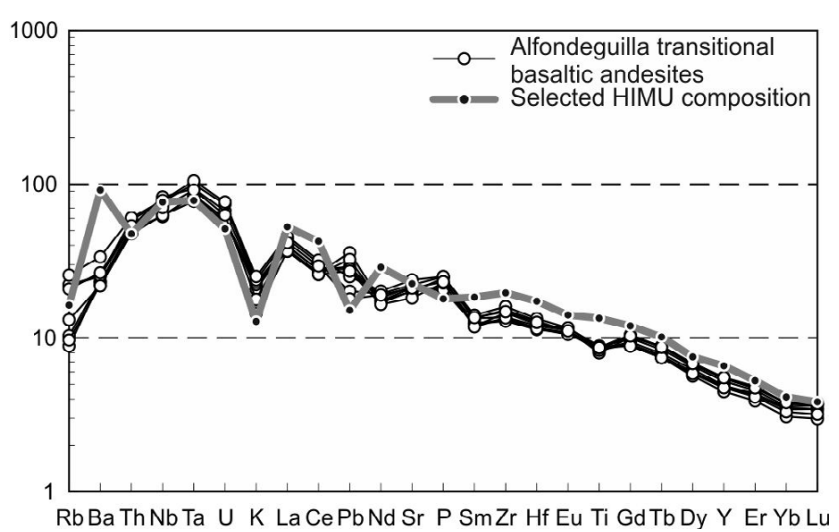

Fig. 10.- Primitive mantle-normalised multielemental diagram of the studied sills. Normalising values are from McDonough and Sun (1995). Selected HIMU composition from Woodhead (1996).

Fig. 10.- Diagrama multielemental de los sills estudiados, normalizado a manto primitivo. Los valores de normalización son de McDonough and Sun (1995). Composición seleccionada de HIMU de Woodhead (1996).

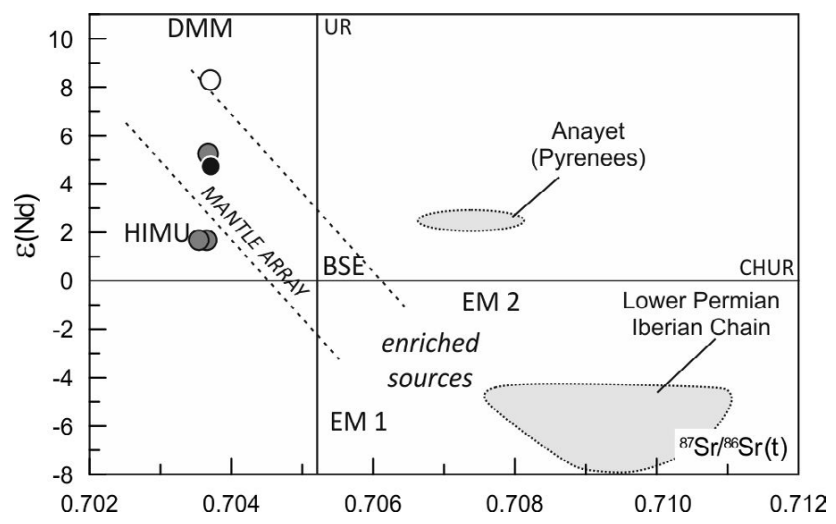

Fig. 11.- Nd-Sr isotopic ratios diagram for the studied sills. Fields for DMM, HIMU, EMI and EMII are from Hart (1988) with updates after Hart et al. (1992). BSE = Bulk Silicate Earth, CHUR = CHondritic Uniform Reservoir. Fields for Anayet and Lower Permian Iberian Chain magmatisms are from Lago et al. (2004a) and Lago et al. (2004b), respectively.

Fig. 11.- Diagrama de relaciones isotópicas Nd-Sr de los sills estudiados. Composiciones de DMM, HIMU, EMI y EMII definidos por Hart (1988) con actualizaciones en Hart el al. (1992). BSE = Promedio de la Tierra Silicatada, CHUR $=$ Reservorio Condrítico Uniforme. Datos de Anayet y Cadena Ibérica (Pérmico Inferior) tomados de Lago et al. (2004a) y Lago et al. (2004b), respectivamente.

equilibrium with amphibole $(\mathrm{Rb} / \mathrm{Sr}<0.06$ and $\mathrm{Ba} / \mathrm{Rb}>$ 20; Furman and Graham, 1999). Hence, in the studied samples $\mathrm{Rb} / \mathrm{Sr}(0.01-0.03)$ and $\mathrm{Ba} / \mathrm{Rb}(12.55-28.79)$ ratios point to amphibole as the K-rich residual phase. The Ti small negative anomaly is unlikely to be related to the retention of opaque minerals in the mantle source, as $\mathrm{Nb}$ and Ta are highly enriched in the studied rocks (Fig. 10). Instead, the aforementioned amphibole residual phase could also retain $\mathrm{Ti}$ if it were a Ti-rich amphibole type (e.g., kaersutite). Therefore, the retention of kaersutite in the mantle source is probably responsible for the de- pletion in alkali elements and Ti observed in the studied sills. The presence of kaersutite as a residual phase during mantle melting has been previously proposed for the Permian sills cropping out in the Pyrenees (Galé, 2005).

\subsection{Age of the Alfondeguilla sill}

No reliable ages were obtained from the ${ }^{40} \mathrm{Ar} /{ }^{39} \mathrm{Ar}$ experiments on whole-rock samples. This is probably due to the high degree of alteration of the samples, even though leached and unleached samples were analysed. Alternatively, the hydrothermal events developed in the Iberian Ranges during the Mesozoic (Tritllá and Solé, 1999) could have opened the Ar system. Indeed, hydrothermal Hg-deposits hosted in the Cañizar Formation are observed in the studied area (Tritllá and Solé, 1999).

However, field criteria can help to constrain the age of the intrusion. First of all, the sill emplaces into the Middle-Upper Permian sedimentary rocks of the Alcotas Formation (De la Horra et al., 2012), defining a maximum age for the hypovolcanic rocks. Furthermore, both the sill and the sedimentary country-rocks are affected by a network of fractures (NNE-SSW and ESE-WNW) compatible with the main Alpine fault directions (Arche and López-Gómez, 1996; De Vicente et al., 2009), defining a minimum age for the sill.

Additionally, the development of billowed margins and peperites, the presence of fragments of structure-less sediments from the country-rocks inside the sill, the presence of vesicles and the composition of clinopyroxene indicate that the magma emplaced into wet, unconsolidated, shallow sediments (see sections 7.1 and 7.2). These arguments imply the sill emplaced shortly after the deposition of the sediments of the Alcotas Formation. Hence, the age of the sill can be defined as Middle-Upper Permian.

Analogous situations of Permian basins where basic sills were emplaced into the Middle-Upper Permian sedimentary rocks have been widely reported throughout the western Tethys and, specifically, in the Pyrenees (e.g., Cinco Villas Massif, Anayet Basin; Bixel, 1988; Galé, 2005; Lago et al., 2004a).

From the above discussion we conclude that the most probable age for the newly found igneous rocks in Alfondeguilla is Middle-Upper Permian, representing the youngest Paleozoic volcanic event found up to now in the Iberian Ranges.

\subsection{Comparison with other Permian magmatisms in the western Tethys}

The transition from late-Variscan events to early Alpine episodes is characterised by two tectono-magmatic cy- 


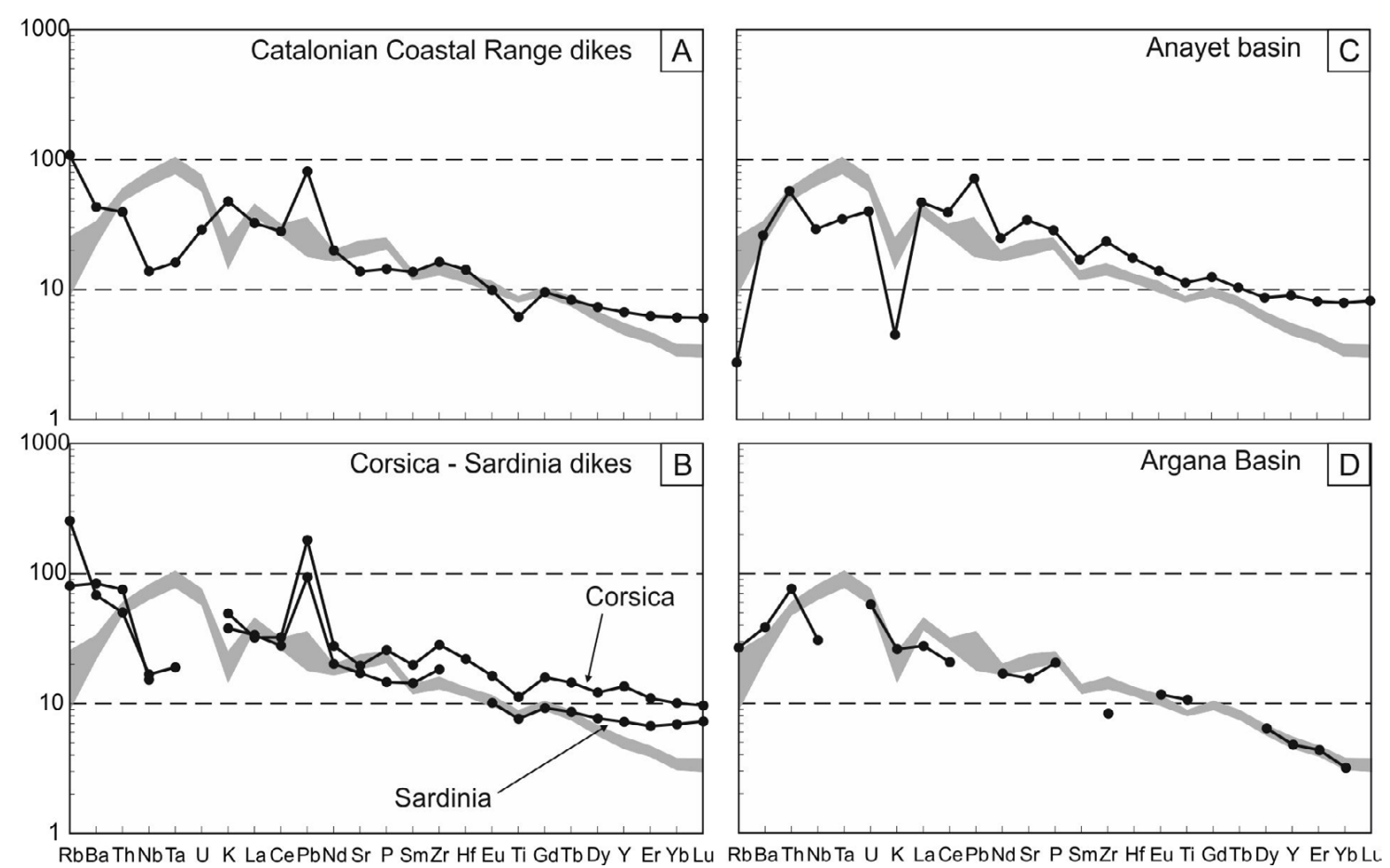

Fig. 12.- Comparison between the studied samples and other Permian magmatisms: Catalonian Coastal Ranges (A), Corsica-Sardinia (B). Anayet Basin (Pyrenees, C) and Argana Basin (High Atlas, D). Data from Aït Chayeb et al. (1998), Buraglini and Traversa (2000), Lago et al. (2004a), Ronca and Traversa (1996) and Ubide et al. (2010).

Fig. 12.- Comparación de las muestras estudiadas con otros magmatismos Pérmicos: Cadenas Costero-Catalanas (A), Córcega-Cerdeña (B), Cuenca de Anayet (Pirineos, C) y Cuenca de Argana (Alto Atlas, D). Datos composicionales de Aït Chayeb et al. (1998), Buraglini y Traversa (2000), Lago et al. (2004a), Ronca y Traversa (1996) y Ubide et al. (2010).

cles in the western Tethys (Bixel, 1988; Bonin, 1988). These cycles reflect the transition from late-Variscan transtension to early Alpine extension and opening of the Neotethys Ocean with progressive westward marine ingression (Cassinis et al., 2012; Lago et al., 2004a). The first cycle ("Orogenic") is composed of calc-alkaline subintrusive acidic to effusive basic-intermediate rocks (Gaggero et al., 2007 and references therein). The second cycle ("Anorogenic") comprises basic and acid rocks traditionally considered alkaline; however, many basic rocks show different geochemical affinities, from tholeiitic to transitional (e.g., Lapierre et al., 1999; Traversa et al. 2003; Ubide et al., 2010). The age of these cycles is believed to be diachronous between the different Tethyan domains, although the "Anorogenic" cycle always postdates the "Orogenic" cycle (Gaggero et al., 2007). Both cycles are mainly comprised during the Permian period (Gaggero et al., 2007). Most datings for the first cycle yield Lower Permian ages, whereas the second cycle was developed from the Middle Permian up to the Middle Triassic (e.g., Dallagiovanna et al., 2009; Gaggero et al., 2007; Vaccaro et al., 1991).

In the Iberian Ranges, the Lower Permian magmatics are rather evolved (andesite-rhyolite) and calc-alkaline, with a clear crustal signature (Lago et al., 2004b). Thus, they are related to the first, "Orogenic" cycle of Bonin (1988). In contrast, the Alfondeguilla sill is basic-intermediate, transitional between subalkaline and alkaline (see section 7.2) and Middle-Upper Permian in age (see section 7.3). Accordingly, it probably belongs to the second, "Anorogenic" cycle. To our knowledge, this is the first report of a magmatism related to the second cycle in the Iberian Ranges.

Most of the basic-intermediate rocks related to the second cycle, mainly those from the Catalonian Coastal Ranges, Corsica-Sardinia and southern France, show similar geochemical features. They present general $\mathrm{Nb}$ (and $\mathrm{Ta})$ depletions and $\mathrm{Pb}$ enrichments relative to the primitive mantle (Fig. 12A, B). Besides, they show low LREE/ HREE fractionation degrees. The available isotopic ratios range from 0.7042 to 0.7075 for ${ }^{87} \mathrm{Sr} /{ }^{86} \mathrm{Sr}$ and from 0.5123 to 0.5131 for ${ }^{143} \mathrm{Nd} /{ }^{144} \mathrm{Nd}$ (Gaggero et al., 2007; Lapierre et al., 1999). These features are typical of volcanic-arc lithospheric magmas related to crustal contamination, pointing to slab-recycling processes in a subduction context (Lapierre et al., 1999; Ronca et al., 1999; Ubide et al., 2011). A major role of phlogopite, instead of amphibole, is recognised for their mantle source (Ubide et al., 2011).

In contrast, the Alfondeguilla sill (Fig. 10) presents high $\mathrm{Nb}$-Ta contents, a marked negative anomaly in $\mathrm{K}$ 
and higher fractionation degrees. These characteristics, together with the isotopic results (Table 2), point to an enriched mantle source with the involvement of a HIMU component. Besides, the relative abundances of alkali elements indicate the presence of amphibole in the mantle source (see section 7.2). These features are not common in other Permian magmatisms related of the western Tethys. We have only observed them in the Anayet Basin in the Pyrenees (Galé, 2005) and in the Argana Basin in the High Atlas (Ait Chayeb et al., 1998) (Fig. 12C, D).

The marked differences in mantle source indicate that the Permian mantle beneath the western Tethys was heterogeneous and variably metasomatised, as suggested in previous studies (Gaggero et al., 2007; Galé, 2005; Lapierre et al., 1999).

\section{Conclusions}

A multiple sill of basaltic andesite hosted by the sedimentary rocks of the Middle-Upper Permian Alcotas Formation is described for the first time in the vicinity of Alfondeguilla village, in the south-eastern Iberian Ranges. The sill was emplaced at shallow levels, shortly after the deposition of the Alcotas Formation, as suggested by field and textural features (presence of billowed margins, peperites, structure-less fragments of sediments and vesicles) and by geochemical criteria (composition of the clinopyroxene crystals). Hence, the age of the sill is inferred to be Middle-Upper Permian. It therefore represents the youngest Paleozoic volcanic event found up to now in the Iberian Ranges. The sill shows a transitional affinity between calc-alkaline and alkaline rocks, similarly to other Permian magmatisms related to the western Tethys.

The geochemical characterisation points to an enriched mantle source with the involvement of a HIMU component. The retention of residual kaersutite in the mantle source is considered the most probable cause for the depletion in alkali elements and Ti observed in the studied samples. Besides, the incorporation of fragments of the host sediments during emplacement would explain the high $\mathrm{SiO}_{2}$ and $\mathrm{Al}_{2} \mathrm{O}_{3}$ contents of the sill.

The compositional features of the Alfondeguilla sill are not very common in the Permian magmatisms of the western Tethys. Most of these magmatisms have a different, subduction- or crustal contamination-related signature, implying that the Permian mantle in this domain was heterogeneous and metasomatised.

\section{Acknowledgements}

This work is a contribution from Projects CGL 200800093, CGL2010-09503-E, CGL2011-24408 of the
Spanish Research Ministry and from Projects UCMBSCH-GR58/08: Análisis de Cuencas (910429) and Paleoclimas (910198) Universidad Complutense-Comunidad Autónoma de Madrid.

\section{References}

Aït Chayeb, E.H., Youbi, N., El-Boukhari, A. Bouabdelli, M., Amrhar, M. (1998): Le volcanisme permien et mésozoïque inférieur du bassin d'Argana (Haut-Atlas occidental, Maroc): un magmatisme intraplaque associé à l'ouverture de l'Atlantique central. Journal of African Earth Sciences 26(4), 499-519. doi:10.1016/S08995362(98)00029-3

Alonso-Azcárate, J., Arche, A., Barrenechea, J. F., López-Gómez, J., Luque, J., Rodas, M. (1997): Palageographical significance of clay mineral assemblages in the Permian and Triassic sediments of the SE Iberian Ranges, eastern Spain. Palaeogeography, Palaeoclimatology, Palaeoecology 136, 309-330. doi:10.1016/S00310182(97)00044-8

Arche, A., López-Gómez, J. (1996): Origin of the Permian-Triassic Iberian Basin, Central-Eastern Spain. Tectonophysics 266, 443-464. doi: 10.1016/S0040-1951(96)00202-8.

Arche, A., López-Gómez, J. (1999): Tectonic and geomorphic controls on the fluvial styles of the Eslida Formation, Middle Triassic, Eastern Spain. Tectonophysics 315, 187-207. doi:10.1016/S00401951(99)00291-7

Arche, A., López-Gómez, J. (2005): Sudden changes in fluvial style across the Permian-Triassic boundary in the eastern Iberian Ranges, Spain: Analysis of possible causes. Palaeogeography, Palaeoclimatology, Palaeoecology 229 (1-2), 104-126. doi: 10.1016/j.palaeo.2005.06.033

Arche, A., López-Gómez, J., Vargas, H. (2002): Propuesta de correlación entre los sedimentos pérmicos y triásicos de la Cordillera Ibérica Este y de las Islas Baleares. Geogaceta 32, 275-278.

Arche, A., López-Gómez, J., Marzo, M., Vargas, H. (2004): The siliciclastic Permian-Triassic deposits in Central and northeastern Iberian Peninsula (Iberian, Ebro and Catalan basins): a proposal for correlation. Geologica Acta 2, 305-320.

Asimow, P. D., Ghiorso, M. S. (1998): Algorithmic modifications extending MELTS to calculate subsolidus phase relations. American Mineralogist 83, 1127-1131.

Befus, K.S., Hanson, R.E., Miggins, D.P., Breyer, J.A., Busbey, A.B. (2009): Nonexplosive and explosive magma/wet-sediment interaction during emplacement of Eocene intrusions into Cretaceous to Eocene strata, Trans-Pecos igneous province, West Texas. Journal of Volcanology and Geothermal Research 181 (3-4), 155-172. doi:10.1016/j.jvolgeores.2008.12.017

Benito, M., De la Horra, R., Barrenechea, J., López-Gómez, J., Rodas, M., Alonso-Azcárate, J., Arche, A., Luque, J. (2005): Late Permian continental sediments in the SE Iberian Ranges, eastern Spain: petrological and mineralogical characteristics and paleoenvironmental significance. Palaeogeography, Palaeoclimatology, Palaeoecology 229, 24-39. doi:10.1016/j.palaeo.2004.12.030

Bixel, F. (1988): Le volcanisme Stéphano-Permian des PyrénéesAtlantiques. Bulletin de Centres de la Recherche Explorationproduction Elf-Aquitanie 12, 661-706.

Bonin, B. (1988): From orogenic to anorogenic environments: evidence from associated magmatic episodes. Schweizerische Mineralogische und Petrographische Mitteilungen 68, 301-311.

Bourquin, S., Bercovici, A., López-Gómez, J., Diez, J.B., Broutin, J., Ronchi, A., Durand, M.,Arche, A., Linol, B., Amour, F. (2011): The Permian-Triassic transition and the onset of Mesozoic sedimen- 
tation at the northwestern peri-Tethyan domain scale: Palaeogeographic maps and geodynamic implications. Palaeogeography, Palaeoclimatology, Palaeoecology 299 (1-2), 265-280. doi: 10.1016/j. palaeo.2010.11.007

Buraglini, N., Traversa, G. (2000): Petrology and mineral chemistry of Late-Hercynian dykes from NW Corsica (France). Periodico di Mineralogia 69 (3), 269-310.

Burchardt and Gudmundsson, (2008)

Cassinis, G., Perotti, C., Ronchi, A. (2012): Permian continental basins in the Southern Alps (Italy) and peri-mediterranean correlations. International Journal of Earth Sciences 101, 129-157. doi:10.1007/ S00531-011-0642-6

Christie-Blick, N., Biddle, K.T. (1985): Deformation and basin formation along strikeslip. In: Biddle, K.T., Christie-Blick, N. (eds), Strike-slip deformation, basin formation and sedimentation. Society of Economic Paleontologists and Mineralogists Special Publication 37, 1-34. doi:10.2110/pec.85.37.0001

Dallagiovanna, G., Gaggero, L., Maino, M., Seno, S., Tiepolo, M. (2009): U-Pb zircon ages for post-Variscan volcanism in the Ligurian Alps (Northern Italy). Journal of the Geological Society 166, 101-114. doi:10.1144/0016-76492008-027

De la Horra, R., Benito, M., López-Gómez, J., Arche, A., Barrenechea, J., Luque, J. (2008): Palaeoenvironmental significance of Late Permian paleosols in the SE Iberian Ranges, Spain. Sedimentology 55, 1849-1873. doi: 10.1111/j.1365-3091.2008.00969.x

De la Horra, R., Galán-Abellán, A.B., López-Gómez, J., Sheldon, N.D., Barrenechea, J.F., Luque, F.J., Arche, A., Benito, M.I. (2012): Paleoecological and paleoenvironmental changes during the continental Middle-Late Permian transition at the SE Iberian Ranges, Spain. Global and Planetary Change 94-95, 46-61. doi: 10.1016/j. gloplacha.2012.06.008

De Vicente, G., Vegas, R. Muñoz-Martín, A., Van Wees, J.D., CasasSáinz, A., Sopeña, A., Sánchez-Moya, Y., Arche, A., López-Gómez, J., Olaiz, A. Fernández-Lozano, J. (2009): Oblique strain partitioning and transpression on an inverted rift: The Castilian Branch of the Iberian Chain. Tectonophysics 470 (3-4), 224-242. doi: 10.1016/j. tecto.2008.11.003

Debon, F., Zimmerman, J.L. (1993): Mafic dykes from some plutons of the Western Pyrenean Axial Zone (France, Spain): markers of the transition from late-Variscan to early-Alpine events. Schweizerische Mineralogische und Petrographische Mitteilungen 73, 421433.

Diéguez, C., De la Horra, R., López-Gómez, J., Benito, M.I., Barrenechea, J., Arche, A., Luque, J. (2007): Late Permian plant remains in the SE Iberian Ranges, Spain: Biodiversity and palaeovegetational significance. Comptes Rendus Palevol 6, 403-411. doi:10.1016/jcrpv.2007.10.001

Doubinger, J., López-Gómez, J., Arche, A. (1990): Pollen and spores from the Permian and Triassic sediments of the Iberian Ranges, Cueva de Hierro (Cuenca) to Chelva- Manzanera (Valencia-Teruel) region, Spain. Review of Palaeobotany and Palynology 66, 25-45. doi:10.1016/0034-6667(90)90027-G

Droop, G.T.R. (1987). A general equation for estimating Fe3+ concentrations in ferromagnesian silicates and oxides from microprobe analyses, using stoichiometric criteria. Mineralogical Magazine 51, 431-435. doi:10.1180/minmag.1987.051.361.10

Frey, F.A., Green, D.H., Roy, S.D. (1978): Integrated models of basalt petrogenesis: a study of quartz tholeiites to olivine melilitites from SE Australia utilizing geochemical and experimental petrological data. Journal of Petrology 19, 463-513. doi:10.1093/petrology/19.3.463

Furman, T., Graham, D. (1999): Erosion of lithospheric mantle beneath the East African Rift system: geochemical evidence from the
Kivu volcanic province. Lithos 48, 237-262. doi:10.1016/S00244937(99)00031-6

Gaggero, L., Oggiano, G., Buzzi, L., Slejko, F., Cortesogno, L. (2007): Post-Variscan mafic dikes from the late orogenic collapse to the Tethyan Rift: evidence from Sardinia. Ofioliti 32(1), 15-37. doi: 10.4454/ofioliti.v32i1.344

Galé, C. (2005): Evolución geoquímica, petrogenética y de condiciones geodinámicas de los magmatismos pérmicos en los sectores central y occidental del Pirineo. PhD Thesis. Universidad de Zaragoza. $457 \mathrm{p}$.

Ghiorso, M.S., Sack, R.O. (1995): Chemical mass transfer in magmatic processes. IV. A revised and internally consistent thermodynamic model for the interpolation and extrapolation of liquid-solid equilibria in magmatic systems at elevated temperatures and pressures. Contributions to Mineralogy and Petrology 119, 197-212. doi:10.1007/BF00307281

Gil, A., Lago., M., Galé, C., Pueyo, Ó., Ubide, T., Larrea, P., Tierz, P. (2011): The lamprophyre dikes in the Panticosa Pluton (Pyrenean Axial Zone): syn-emplacement with later-hercynian extension. Geogaceta 50-1, 51-54.

Hart, S.R. (1988): Heterogeneous mantle domains - signatures, genesis and mixing chronologies. Earth and Planetary Science Letters 90, 273-296. doi:10.1016/0012-821X(88)90131-8

Hart, S.R., Hauri, E.H., Oschmann, L.A., Whitehead, J.A. (1992): Mantle plumes and entrainment: isotopic evidence. Science 256, 517-520. doi:10.1126/science.256.5056.517

Hoffman, A.W. (1997): Mantle geochemistry: the message from oceanic volcanism. Nature 385, 219-229. doi:10.1038/385219a0

Huppert, H.E., Sparks, R.S.J. (1980): Restrictions on the compositions of mid-ocean ridge basalts: a fluid dynamical investigation. Nature 286, 46-48. doi:10.1038/286046a0

Jaeger, J.C. (1968): Cooling and solidification of igneous rocks. In: Hess, H.H., Poldervaart, A. (eds.), Basalts: The Poldervaart Treatise on Rocks of Basaltic Compositions. Wiley Interscience, New York, p. 503-536.

Kano, K. (1991): Miocene pillowed sills in the Shimane Peninsula, SW Japan. Journal of Volcanology and Geothermal Research 48, 359-366. doi:10.1016/0377-0273(91)90051-Z

Kano, K. (2002): Middle Miocene volcaniclastic dikes at Kukedo, Shimane Peninsula, SW Japan: fluidization of volcaniclastic beds by emplacement of syn-volcanic andesitic dikes. Journal of Volcanology and Geothermal Research 114, 81-94. doi:10.1016/S03770273(01)00283-9

Kokelaar, B.P. (1982): Fluidization of wet sediments during the emplacement and cooling of various igneous bodies. Journal of the Geological Society 139, 21-33. doi:10.1144/gsjgs.139.1.0021

Lago, M., Arranz, E., Pocoví, A., Galé, C., Gil-Imaz, A. (2004a): Permian magmatism and basin dynamics in the Southern Pyrenees: a record of transition from late Variscan transtension to early Alpine extension. In: Wilson, M., Neumann, E.-R., Davies, G.R., Timmerman, M.J., Heeremans, M., Larsen, B.T. (eds.), PermoCarboniferous magmatism and rifting in Europe. Geological Society, London, Special Publications 223, 439-464. doi:10.1144/GSL. SP.2004.223.01.19

Lago, M., Arranz, E., Pocoví, A., Galé, C., Gil-Imaz, A. (2004b): Lower Permian magmatism of the Iberian Chain, Central Spain, and its relationship to extensional tectonics. In: Wilson, M., Neumann, E.-R., Davies, G.R., Timmerman, M.J., Heeremans, M., Larsen, B.T. (eds.), Permo-Carboniferous magmatism and rifting in Europe. Geological Society, London, Special Publications 223, 465-490. doi:10.1144/GSL.SP.2004.223.01.20

Lapierre, H., Basile, C., Dupuis, V. (1999): Basaltes et trachytes permiens de l'Esterel (SE France); une serie tholeiitique transitionnelle 
epanchee pendant l'amincissement lithospherique. Bulletin de la Société Géologique de France 170(2), 253-265.

Lavine, A. and Aalto, K.R. (2002): Morphology of a crater-filling lava lake margin, The Peninsula tuff cone, Tule Lake National Wildlife Refuge, California: implications for formation of peperite textures. Journal of Volcanology and Geothermal Research 114, 147-163. doi:10.1016/S0377-0273(01)00285-2

Latypov, R.M. (2003): The origin of marginal compositional reversals in basic-ultrabasic sills and layered intrusions by Soret fractionation. Journal of Petrology 44, 1579-1618. doi:10.1093/petrology/ egg050

Le Bas, M.J., Le Maitre, R.W., Streckeisen, A., Zanettin, B. (1986): A chemical classification of volcanic rocks based on the total alkalisilica diagram. Journal of Petrology 27, 745-750.

Le Maitre, R.W. (ed) (2002): Igneous Rocks. A Classification and Glossary of Terms. Cambridge University Press, Cambridge. 236p.

Leat, P.T. and Thompson. R.N. (1988): Miocene hydrovolcanism in NW Colorado, USA, fueled by explosive mixing of basic magma and wet unconsolidated sediment. Bulletin of Volcanology 50, 229243. doi:10.1007/BF01047486

Leterrier, J., Mauri, R.C., Thonon, P., Girard, D., Marchal, M. (1982): Clinopyroxenes composition as a method identification of the magmatic affinities of paleo-volcanic series. Earth and Planetary Science Letters 59, 139-154. doi:10.1016/0012-821X(82)90122-4

López-Gómez, J., Arche, A., Pérez-López, A. (2002): Permian and Triassic. In: W. Gibbon, T. Moreno (eds.), The Geology of Spain. Geological Society, London, 185-212.

López-Gómez, J., Arche, A., Marzo, M., Durand, M. (2005): Stratigraphical and palaeogeographical significance of the continental sedimentary transition across the Permian-Triassic boundary in Spain. Palaeogeography, Palaeoclimatology, Palaeoecology 229, 3-23. doi:10.1016/j.palaeo.2004.11.028

McCoy-West, A.J., Baker, J.A., Faure, K., Wysoczanski, R. (2010): Petrogenesis and origins of Mid-Cretaceous continental intraplate volcanism in Marlborough, New Zealand: Implications for the longlived HIMU magmatic mega-province of the SW Pacific. Journal of Petrology 51, 2003-2045. doi:10.1093/petrology/egq046

Morimoto, N., Fabries, J., Ferguson, A.K., Ginzburg, I.V., Ross, M., Seifert, F.A., Zussman, J., Aoki, K., Gottardi, G. (1988) Nomenclature of pyroxenes. Mineralogical Magazine 52, 535-550. doi:10.1180/minmag.1988.052.367.15

Németh, K. Martin, U. (2007): Shallow sill and dyke complex in western Hungary as a possible feeding system of phreatomagmatic volcanoes in "soft-rock" environment. Journal of Volcanology and Geothermal Research 159, 138-152. doi:10.1016/j.jvolgeores.2006.06.014

Nimis, P. (1995): A clinopyroxene geobarometer for basaltic systems based on crystal-structure modelling. Contributions to Mineralogy and Petrology 121, 115-125. doi:10.1007/s004100050093

Pankhurst, R.J., O’Nions, R.K. (1973): Determination of Rb/Sr and ${ }^{87} \mathrm{Sr} /{ }^{86} \mathrm{Sr}$ ratios of some standard rocks and evaluation of X-ray fluorescence spectrometry in Rb-Sr geochemistry. Chemical Geology 12, 127-136. doi:10.1016/0009-2541(73)90110-1

Ronca, S., Traversa, G. (1996): Late-Hercynian dyke magmatism of Sarrabus (SE Sardinia). Periodico di Mineralogia 65, 35-70.

Ronca, S., Del Moro, A., Traversa, G. (1999): Geochronology, Sr-Nd isotope geochemistry and petrology of late-Hercynian dyke magmatism from Sarrabus (SE Sardinia). Periodico di Mineralogia 68 (3), 231-260.

Shervais, J.W. (1982): Ti-V plots and the petrogenesis of modern and ophiolitic lavas. Earth and Planetary Sciences Letters 59, 101-118.
doi:10.1016/0012-821X(82)90120-0

Skilling, I.P., White, J.D.L., McPhie, J. (2002). Peperite: a review of magma-sediment mingling. Journal of Volcanology and Geothermal Research 114, 1-17. doi:10.1016/S0377-0273(01)00278-5

Traversa, G. (2000):

Traversa, G., Ronca, S., Del Moro, A., Pasquali, C., Buraglini, N., Barabino, G. (2003): Late to post-hercynian dyke activity in the Sardinia-Corsica domain: a transition from orogenic calc-alkaline to anorogenic alkaline magmatism. Bolletino della Societá Geologica Italiana, Vol. Esp. 2, 131-152.

Tritllá, J., Solé, J. (1999). A newly dated Cretaceous hydrothermal event in the Iberian Ranges (Eastern Spain) and its significance within the Mesozoic thermal history in the Iberian Peninsula. Ore Geology Reviews 15, 243-259. doi:10.1016/S0169-1368(99)00009-8

Ubide, T., Lago, M., Arranz, E., Galé, C., Larrea, P. (2010): The lamprophyric sub-vertical dyke swarm from Aiguablava (Catalonian Coastal Ranges): petrology and composition. Geogaceta 49, 83-86.

Ubide, T., Galé, C., Arranz, E., Lago, M., França, Z., Larrea, P., Tierz, P. (2011): Subduction-related signature in late-Variscan lamprophyres from the Catalonian Coastal Ranges (northeast Spain). Abstract Proceedings of the XXV IUGG General Assembly (Melbourne), p. 1924.

Vaccaro, C., Atzori, P., Del Moro, A., Oddone, M., Traversa, G., Villa, I.G. (1991): Geochronology and Sr isotope geochemistry of LateHercynian dykes from Sardinia. Schweizerische mineralogische und petrographische Mitteilungen 71, 221-230.

Van Wees, J.D., Arche, A., Beigdorf, C., López-Gómez, J., Cloetingh, S. (1998): Temporal and spatial variations in tectonic subsidence in the Iberian Basin (E. Spain). Inferences from automated forward modelling of high resolution stratigraphy (Permian-Mesozoic). Tectonophysics 300, 285-310. doi:10.1016/S0040-1951(98)00244-3

Vargas, H., Gaspar-Escribano, J., López-Gómez, J., Van Wees, J.D., Cloetingh, S., De la Horra, R., Arche, A. (2009): A comparison of the Iberia and Ebro basins during the Permian and Triassic, eastern Spain: A quantitative subsidence modelling approach. Tectonophysics 474, 160-183. doi:10.1016/j.tecto.2008.06.005

Walker, G.P.L. (1992): Morphometric study of pillow-size spectrum among pillow lavas. Bulletin of Volcanology 54, 459-474. doi:10.1007/BF00301392

White, J.D.L., McPhie, J., Skilling, I., (2000): Peperite: a useful genetic term. Bulletin of Volcanology 62, 65-66. doi:10.1007/ s004450050293

Whitney, D.L., Evans, B.W. (2010): Abbreviations for names of rockforming minerals. American Mineralogist 95, 185-187.

Winchester, M.A., Floyd, P.A. (1977): Geochemical discrimination of different magma series and their differentiation products using inmobile elements. Chemical Geology 20, 325-343. doi:10.1016/0009-2541(77)90057-2

Woodhead J. (1996): Extreme HIMU in an oceanic setting: the geochemistry of Mangaia Island (Polynesia), and temporal evolution of the Cook-Austral hotspot. Journal of Volcanology and Geothermal Research 72, 1-19. doi:10.1016/0377-0273(96)00002-9

Zindler, A., Hart, S. (1986): Chemical Geodynamics. Annual Review of Earth and Planetary Sciences 14, 493-571. doi:10.1146/annurev. earth.14.1.493 